\title{
ARE ALL INTERIM CEOS CREATED EQUAL? \\ EVIDENCE FROM INVESTOR PERCEPTIONS \\ AND CEO BEHAVIOR
}

by

\author{
LEAH BAER
}

B.S., Illinois State University, 2011

M.S.A., Illinois State University, 2013

\author{
A thesis submitted to the \\ Faculty of the Graduate School of the \\ University of Colorado in partial fulfillment \\ of the requirement for the degree of \\ Doctor of Philosophy \\ Department of Accounting \\ 2018
}


This thesis entitled:

Are All Interim CEOs Created Equal? Evidence from Investor Perceptions and CEO Behavior written by Leah Baer

has been approved for the Department of Accounting

Yonca Ertimur

Steve Rock

Date

The final copy of this thesis has been examined by the signatories, and we find that both the content and the form meet acceptable presentation standards of scholarly work in the above mentioned discipline. 
Baer, Leah (Ph.D., Accounting)

Are All Interim CEOs Created Equal? Evidence from Investor Perceptions and CEO Behavior

Thesis directed by Professor Yonca Ertimur

I examine the market perception of different types of interim CEO successions and whether market expectations are in line with CEO behavior. Using a hand-collected dataset, I find that there are two types of interim CEOs: aspiring and place-holding. I find that the market perceives the appointment of place-holding interim CEOs as bad news and the appointment of aspiring interim CEOs as similar to the appointment of permanent CEOs. I further study actions taken by interim CEOs and do not find evidence that aspiring interim CEOs act myopically. Rather they appear to invest more in discretionary expenses, such as research and development, which suggests that they focus on increasing long-term shareholder value. Thus, market expectations of aspiring interim CEOs are in line with CEO behavior. In addition, analysis of CEO effort suggests that placeholding interim CEOs exert less effort than permanent CEOs. I find preliminary evidence that they issue less accurate forecasts. Overall, this paper provides initial evidence consistent with career concerns of interim CEOs resulting in different $\mathrm{CEO}$ behavior. 


\section{ACKNOWLEDGEMENTS}

I would like to thank my dissertation committee: Yonca Ertimur (chair), Alan Jagolinzer, Steve Rock, Frances Tice, and Sarah Zechman for their feedback and support. I would also like to thank Tony Ding, Nathan Marshall, Elaine Mauldin, Tathagat Mukhopadhyay, Caleb Rawson, Nikki Skinner, Andy Stephan, and workshop participants from the University of Colorado Boulder and the University of Missouri for their comments and suggestions. 


\section{CONTENTS}

\section{CHAPTER}

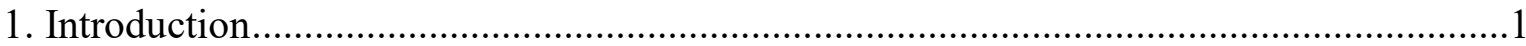

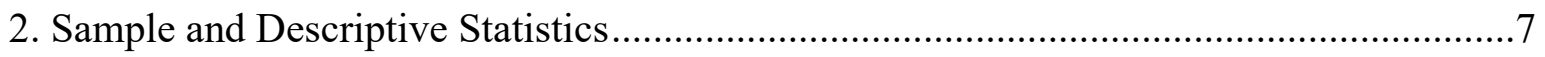

2.1. Sample Construction and Data Collection...................................................

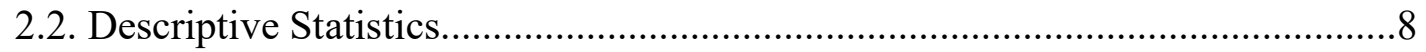

3. Related Literature and Hypothesis Development ................................................. 15

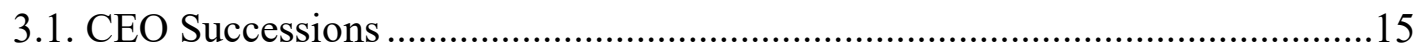

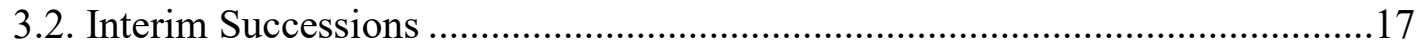

3.3. Hypothesis Development.................................................................... 18

4. Market Reaction: Research Design and Results .....................................................21

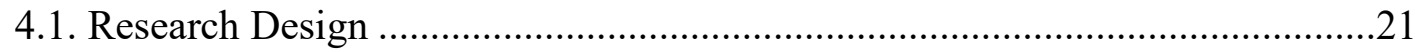

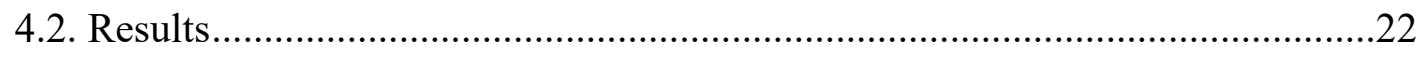

5. CEO Behavior: Research Design and Results .........................................................25

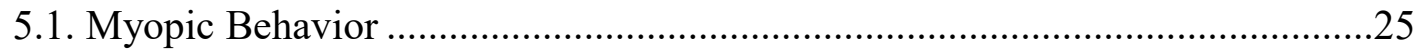

5.1.1. Measurement of key variables .....................................................26

Proxies for accruals management .............................................26

Proxy for real activities management .........................................27

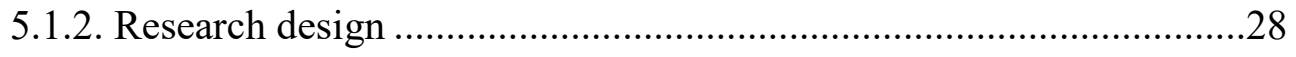

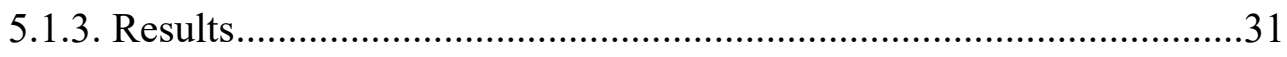

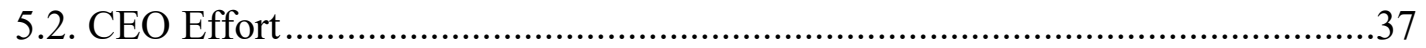

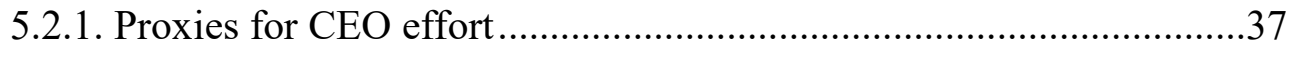

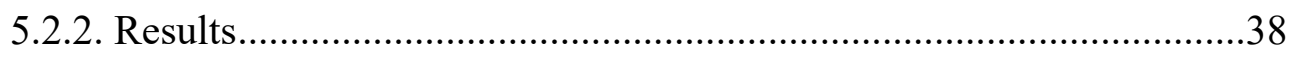





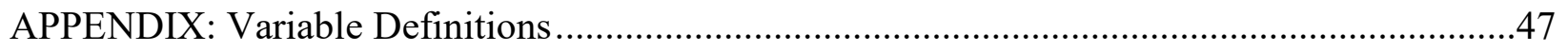




\section{TABLES}

Table

1. Descriptive Statistics: Successor CEOs and Turnover Circumstances...........................9

2. Descriptive Statistics: Tenure and Career Outcomes of Interim CEOs..........................13

3. Market reaction: CEO appointments ...................................................................23

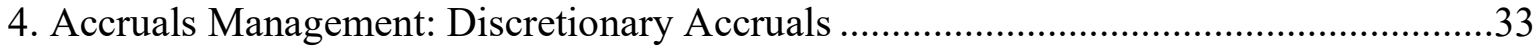

5. Accruals Management: Performance-Matched Discretionary Accruals .........................34

6. Real Activities Management: Abnormal Discretionary Expenses .................................36

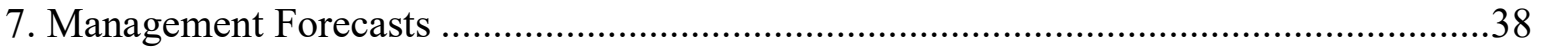




\section{CHAPTER 1}

\section{INTRODUCTION}

Prior studies show that individual CEOs impact corporate behavior and decisions (e.g., Bertrand and Schoar, 2003; Malmendier and Tate, 2005; Bamber, Jiang, and Wang, 2010; Dyreng, Hanlon, and Maydew, 2010). The key decision-making role of CEOs combined with the frequent occurrence of CEO turnover (at about 17\% of Fortune 500 firms annually) highlight the importance of CEO successions. Indeed, investors and boards view successions as important events. Shareholders react positively to CEO successions on average and negatively when the CEO leaves for a CEO position at another firm (e.g., Hayes and Schaefer, 1999; Huson, Parrino, and Starks, 2001). CEO succession is among the top five discussions that boards have with shareholders (Spencer Stuart, 2017). While most firms appoint a permanent CEO subsequent to turnover, approximately $20 \%$ of CEO successions involve firms hiring an interim CEO before appointing a permanent CEO (Ballinger and Marcel, 2010). Additionally, there is likely variation in incentives, particularly career concerns, amongst interim CEOs. In this paper, I provide descriptive information regarding interim successions and examine (1) the market's perception of different types of interim successions and (2) whether market expectations are in line with CEO behavior.

Because existing databases do not reliably identify interim CEOs, I hand collect data by reading turnover announcements for a random sample of 1,000 turnovers. ${ }^{1}$ I classify successions as interim if the disclosure clearly identifies the CEO as temporary. In my final sample, approximately $22 \%$ of successions are interim. Most interim successions are the result of

\footnotetext{
${ }^{1}$ My final sample is comprised of 943 CEO successions. In future iterations of the paper, I plan to expand the sample to include all turnovers at S\&P 1500 firms over the 2002-2015 period.
} 
unanticipated turnovers (e.g., forced turnovers and health-related departures). An important distinction between interim and permanent CEOs is the shorter horizon of interim CEOs. In my sample, interim CEOs are in the interim position, on average, for six months.

Prior literature views interim CEOs as a homogenous group and suggests that stronger career concerns (i.e., desire to obtain permanent CEO position) and short horizons will lead them to engage in myopic behavior (Chen, Luo, Tang, and Tong, 2015a). In contrast, I argue that there are two types of interim CEOs with variation in career concerns: those who have stronger career concerns and are more likely to aspire to be a permanent CEO (aspiring interim CEOs) and those who have weaker career concerns and do not seek a permanent CEO position (place-holding interim CEOs).

In my sample, two distinct groups of interim CEOs emerge. 39\% of interim CEOs are lower-level executives of the firm immediately prior to appointment as interim CEO. The CEO position is highly desired among lower-level executives (Korn Ferry, 2014), possibly because the associated monetary and non-monetary benefits are greater. Thus, I expect these interim CEOs to aspire to be permanent CEOs (i.e., aspiring interim CEOs). Conversely, 54\% of interim CEOs are non-executive directors of the firm immediately prior to appointment as CEO. These interim CEOs are significantly older than permanent CEOs and other interim CEOs. Thus, I conjecture that, because these interim CEOs are significantly closer to retirement age, they are more likely to be place-holding interim CEOs. ${ }^{2}$

\footnotetext{
${ }^{2}$ Very few interim CEOs (approximately 2.5\%) come directly from an external position. About $1.5 \%$ of interim successions involve the appointment of a committee, rather than an individual, to fulfil the duties of the $\mathrm{CEO}$ temporarily.
} 
Due to short horizons (i.e. short tenure to show ability as CEO) and stronger career concerns, I expect aspiring interim CEOs to be more likely to engage in myopic behavior than permanent CEOs. Thus, I expect the market to anticipate myopic behavior by aspiring interim CEOs and perceive appointments of aspiring interim CEOs as bad news relative to appointments of permanent CEOs. Place-holding interim CEOs have short horizons and do not have strong career concerns, so I expect them to exert less effort than permanent CEOs. I expect the market to anticipate place-holding interim CEOs to exert less effort and perceive appointments of placeholding interim CEOs as bad news relative to appointments of permanent CEOs. Overall, I expect the market to perceive the appointment of interim CEOs as bad news, albeit for different reasons.

I examine two-day market reactions, beginning on the day of the announcement, to CEO appointments and find that, consistent with the market perceiving interim CEO successions as bad news, there is a negative and significant market reaction to announcements of interim CEO appointments. Moreover, the average negative market reaction is driven by place-holding interim CEOs. This is consistent with place-holding interim CEOs being perceived as not exerting as much effort or as making lower quality decisions with respect to permanent CEOs. Additionally, the market reaction to the appointment of place-holding interim CEOs is significantly more negative than the market reaction to the appointment of aspiring interim CEOs, suggesting that the market anticipates place-holding interim CEOs to damage firm value more than aspiring interim CEOs. Lastly, inconsistent with the market anticipating myopic behavior by aspiring interim CEOs, the market reaction to the appointment of aspiring interim CEOs is not significantly different from the appointment of permanent CEOs. In the remaining portions of the paper, I examine myopic behavior and CEO effort to determine whether the market reaction (or lack thereof) is warranted. 
To proxy for myopic behavior, I examine whether CEOs manage earnings, either through accruals or real activities management (Roychowdhury, 2006; Dechow, Ge, and Schrand, 2010; Cohen and Zarowin, 2010). Using the modified Jones (1991) approach to calculate signed discretionary accruals and performance-matched accruals as proxies for earnings management, I do not find evidence that interim CEOs are more likely to manage earnings upwards (i.e., have larger discretionary accruals) than permanent CEOs. Rather, and inconsistent with managing earnings upwards, I find that firms with aspiring interim CEOs have significantly lower performance-matched discretionary accruals during the first and second quarters subsequent to the turnover than firms with permanent CEOs.

CEOs can also manage earnings via real activities management by reducing discretionary expenses (i.e., research and development, selling, general, and administrative expenses). Inconsistent with interim CEOs acting myopically and managing earnings upwards, I find that firms with interim CEOs have higher discretionary expenses during the first quarter subsequent to the turnover relative to firms with newly appointed permanent CEOs. This result is driven by firms with aspiring interim CEOs.

Overall, I do not find evidence of interim CEOs acting myopically to manage earnings upwards. Rather, possibly to develop a reputation as a capable CEO and increase shareholder value in the long-term, aspiring interim CEOs appear to invest more in R\&D and SG\&A than newly appointed permanent CEOs. Thus, the non-negative market reaction to the appointment of interim CEOs relative to permanent CEOs may be warranted. Furthermore, I find no significant difference in either type of earnings management between permanent CEOs and place-holding interim CEOs. These findings are in contrast to Chen et al. (2015a) who report that firms with interim CEOs 
manage earnings upwards in order to increase the probability of obtaining the permanent CEO position.

Next, I provide preliminary evidence on whether place-holding interim CEOs exert less effort than permanent CEOs using characteristics of management forecasts. Management forecasts are a voluntary disclosure, thus firms that issue them agree to devote more time and exert effort to develop informative forecasts. I proxy for CEO effort in three ways: (1) the likelihood of issuing a management forecast, (2) the accuracy of management forecasts, and (3) the number of measures forecasted during the quarter. Because of significant sample attrition when examining management forecasts, I only conduct univariate analysis. There is no evidence that firms with place-holding interim CEOs are less likely to issue forecasts or forecast a fewer number of measures than firms with permanent CEOs. Next, I examine absolute forecast accuracy and find that firms with interim CEOs issue less accurate management forecasts during the quarter of the turnover than firms with permanent CEOs. Consistent with lack of effort and knowledge, I find that this result is driven by place-holding interim CEOs.

I primarily contribute to the literature on CEO successions. First, I show that not all interim successions are perceived to be bad news. Rather, there are two types of interim successors: aspiring and place-holding CEOs. Only the appointment of place-holding interim CEOs, who may not aspire to the permanent CEO position, is perceived as bad news. The market reacts to the appointments of aspiring interim CEOs, who may aspire to a permanent CEO position, similar to appointments of permanent CEOs, suggesting that the market perceives them as bringing similar value to the firm. Additionally, I show that interim CEOs, particularly aspiring interim CEOs, do not engage in myopic behavior, in contrast to results reported in Chen et al. (2015a). In particular, I do not find any evidence consistent with interim CEOs managing earnings upwards, either 
through accruals or real activities management. Rather, the results indicate that interim CEOs begin to make changes to real activities that could enhance long-term firm value. Second, I provide a reliable dataset identifying interim CEOs that will be useful in future research. Overall, I contribute to the literature by showing that not all interim CEOs behave the same due to career concerns. 


\section{CHAPTER 2}

\section{SAMPLE AND DESCRIPTIVE STATISTICS}

\subsection{Sample Construction and Data Collection}

Machine-readable databases do not reliably identify interim CEOs. ${ }^{3}$ Thus, I hand collect information for each CEO turnover in my initial sample to determine whether the successor is an interim or permanent CEO. To construct the initial sample, I proceed as follows. First, I identify all CEO turnovers at S\&P 1500 firms between 2002 and 2015 using ExecuComp. I rely on the date the executive became CEO (ExecuComp item BecameCEO) and the date the executive left the CEO position (ExecuComp item LeftOFC) to capture the fiscal years during which an executive was the CEO. ${ }^{4}$ I then identify unique turnover firm-years by retaining the first and last year each CEO was in the CEO position. The predecessor CEO is the individual who holds the CEO position at the beginning of a turnover firm-year and the successor CEO is the individual who holds the position at the end of each turnover firm-year. ${ }^{5}$ This yields an initial sample of 3,418 turnovers. ${ }^{6}$

Second, given the time-consuming nature of the hand collection process, I construct a random sub-sample of 1,000 observations. I begin my hand collection process by obtaining 8 -Ks

${ }^{3}$ I identify 203 interim successions through hand collection, ExecuComp and AuditAnalytics accurately identifies 56 and 111 of these, respectively.

${ }^{4}$ ExecuComp includes a CEO indicator (ExecuComp item CEOAnn) which captures the executive who served as CEO for all or most of the fiscal year. Because this indicator will not capture CEOs who hold the position for a short period of time during the turnover year, I use the dates present as CEO to create an indicator.

${ }^{5}$ This approach does not always identify the correct predecessor and successor. For example, if turnover occurs at the end of a fiscal year, this method may identify the predecessor and successor as the same CEO. If the entirety of a CEO's tenure is captured within one fiscal year, this CEO may also not be identified. Through the hand collection process, I correct these types of issues.

${ }^{6}$ As mentioned in footnote 6, this approach may identify two turnovers for one succession, particularly if the turnover occurs at year-end. Thus, there may be fewer than 3.418 successions. Since it is difficult to identify turnover announcement dates as well as firm consequences for turnovers related to mergers, acquisitions, and spin-offs, I exclude these turnovers from my final sample. Due to time constraints with the hand collection process, I also exclude turnovers that did not have an 8-K turnover-related announcement six months prior to or one month subsequent to the turnover. In future iterations of the paper, I plan to expand the sample to increase the power and generalizability of my tests. 
disclosing the turnover announcement. I read each $8-\mathrm{K}$ and the attached press release to identify (i) the successor, the predecessor, and turnover date (making corrections to data from ExecuComp as needed), (ii) whether the successor or predecessor is an interim CEO, (iii) the stated reason for the departure of the predecessor and whether, and in what capacity, the predecessor stays with the firm, and (iv) the successor's relationship with the firm prior to the appointment. If the successor $\mathrm{CEO}$ is an interim $\mathrm{CEO}$, I also collect data on when the interim CEO departs the interim position and whether the interim CEO obtains the permanent CEO position. I exclude 57 of the 1,000 turnovers that identify an interim CEO as the predecessor. This process results in a final sample of 943 successions of which, 203 (21.5\%) successions are interim.

\subsection{Descriptive Statistics}

Because there is little systematic evidence regarding the circumstances of interim successions and the types of interim CEOs, I first provide descriptive information for my sample. Table 1 Panel A presents descriptive statistics on the relationship between the firm and the successor CEO immediately prior to appointment. 39\% of interim CEOs were lower-level executives of the firm immediately prior to appointment as interim CEO, while $54 \%$ of interim CEOs were non-executive directors of the firm. In contrast, $67 \%$ (13\%) of permanent CEOs were lower-level executives (non-executive directors) of the firm immediately prior to appointment as CEO. Consistent with a lack of succession plan leading to interim successions (Mooney, Semadeni, and Kesner, 2014), there are fewer interim CEOs who were Presidents or COOs of the firm immediately prior to appointment than there are interim CEOs who were CFOs, VPs, or other lower-level executives. ${ }^{7}$ Perhaps consistent with the board having little time to find an adequate 2006).

\footnotetext{
${ }^{7}$ Prior literature proxies for succession plans with the existence of a Chief Operating Officer (COO) (Naveen,
} 
permanent replacement, very few interim CEOs are external hires. Additionally, there are a few interim CEO positions that are filled by committees or co-CEOs (Other-Other). Because of the small sample, I exclude interim CEOs who were external hires from analysis. I also exclude observations when multiple individuals are performing CEO duties (i.e. co-CEOs or committeeCEOs) since it is difficult to separate individual behavior and incentives.

Table 1: Descriptive Statistics: Successor CEOs and Turnover Circumstances

Panel A: Successor CEO prior to Appointment

\begin{tabular}{|c|c|c|c|c|c|}
\hline \multirow[b]{2}{*}{ Non-Executive Director } & \multicolumn{2}{|c|}{$\begin{array}{c}\text { Interim } \\
(\mathrm{N}=203)\end{array}$} & \multicolumn{2}{|c|}{$\begin{array}{c}\text { Permanent } \\
(\mathrm{N}=740)\end{array}$} & \multirow{2}{*}{$\begin{array}{c}\begin{array}{c}\text { Test of } \\
\text { differences }\end{array} \\
* * *\end{array}$} \\
\hline & $53.69 \%$ & & $12.57 \%$ & & \\
\hline NED - Chairman & & $44.04 \%$ & & $39.78 \%$ & \\
\hline NED - Non-Chairman & & $55.96 \%$ & & $60.22 \%$ & \\
\hline Total Non-Executive Director & & $100.00 \%$ & & $100.00 \%$ & \\
\hline Lower-Level Executive & $38.92 \%$ & & $66.89 \%$ & & $* * *$ \\
\hline LLE - President/COO & & $24.05 \%$ & & $74.75 \%$ & $* * *$ \\
\hline$L L E-C F O$ & & $36.71 \%$ & & $6.87 \%$ & $* * *$ \\
\hline$L L E-V P$ & & $26.58 \%$ & & $11.92 \%$ & $* * *$ \\
\hline LLE - Other & & $12.66 \%$ & & $6.46 \%$ & $* *$ \\
\hline Total Lower-Level Executive & & $100.00 \%$ & & $100.00 \%$ & \\
\hline Other & $7.39 \%$ & & $20.54 \%$ & & $* * *$ \\
\hline Other - External & & $33.33 \%$ & & $87.18 \%$ & *** \\
\hline Other - Other & & $66.67 \%$ & & $12.82 \%$ & $* * *$ \\
\hline \multirow{2}{*}{ Total Other } & & \multirow[t]{2}{*}{$100.00 \%$} & & $100.00 \%$ & \\
\hline & $100.00 \%$ & & $100.00 \%$ & & \\
\hline
\end{tabular}


Panel B: Firm and CEO Characteristics

\begin{tabular}{|c|c|c|c|c|c|c|c|c|c|c|}
\hline \multirow[b]{3}{*}{ Successor Age } & \multicolumn{2}{|c|}{$\begin{array}{c}\text { Permanent } \\
\text { (1) }\end{array}$} & \multicolumn{2}{|c|}{$\begin{array}{l}\text { Interim } \\
\text { (2) }\end{array}$} & \multirow[t]{2}{*}{$\begin{array}{l}\text { (1) } \\
\text { vs. } \\
(2)\end{array}$} & \multicolumn{2}{|c|}{$\begin{array}{c}\text { Interim - } \\
\text { Lower-Level } \\
\text { (3) }\end{array}$} & \multicolumn{2}{|c|}{$\begin{array}{l}\text { Interim - } \\
\text { Director } \\
\quad(4)\end{array}$} & \multirow[t]{2}{*}{$\begin{array}{l}\text { (3) } \\
\text { vs. } \\
(4)\end{array}$} \\
\hline & $\mathrm{N}$ & Mean & $\mathrm{N}$ & Mean & & $\mathrm{N}$ & Mean & $\mathrm{N}$ & Mean & \\
\hline & 737 & 52.60 & 183 & 57.01 & $* * *$ & 79 & 51.561 & 104 & 61.14 & 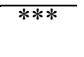 \\
\hline Predecessor Stay & 737 & $67.03 \%$ & 183 & $24.59 \%$ & $* * *$ & 79 & $26.58 \% \quad 1$ & 104 & $23.08 \%$ & \\
\hline Stay-Chairman & 494 & $72.27 \%$ & 45 & $17.78 \%$ & $* * *$ & 21 & $28.57 \%$ & 24 & $8.33 \%$ & ${ }^{*}$ \\
\hline Stay - Transition & 494 & $12.55 \%$ & 45 & $46.67 \%$ & $* * *$ & 21 & $52.38 \%$ & 24 & $41.67 \%$ & \\
\hline Predecessor Age & 693 & 60.67 & 174 & 55.62 & $* * *$ & 75 & 56.83 & 99 & 54.71 & ** \\
\hline Predecessor Tenure & 734 & 9.62 & 183 & 5.92 & $* * *$ & 79 & 6.721 & 104 & 5.31 & * \\
\hline Firm Size & 718 & 7.63 & 180 & 6.84 & *** & 77 & 6.841 & 103 & 6.84 & \\
\hline$R O A$ & 726 & 0.01 & 181 & -0.01 & *** & 78 & $-0.01 \quad 1$ & 103 & -0.01 & \\
\hline$B T M$ & 717 & 0.56 & 180 & 0.63 & & 77 & $0.79 \quad 1$ & 103 & 0.50 & ** \\
\hline Firm Age & 726 & 3.14 & 181 & 3.04 & * & 78 & 3.061 & 103 & 3.03 & \\
\hline Leverage & 681 & 0.24 & 167 & 0.20 & * & 70 & 0.17 & 97 & 0.23 & $*$ \\
\hline \multicolumn{11}{|c|}{ Panel C: Departure of Predecessor CEO } \\
\hline & & $\begin{array}{r}\text { Perman } \\
(\mathrm{N}=73 \\
\quad(1)\end{array}$ & & $\begin{array}{c}\text { Interim } \\
(\mathrm{N}=183) \\
(2)\end{array}$ & $\begin{array}{l}(1 \\
\mathrm{vs} \\
(2\end{array}$ & $\begin{array}{l}\text { 1) } \\
\text { s. } \\
\text { 2) }\end{array}$ & $\begin{array}{c}\text { Interim - } \\
\text { Lower-Level } \\
(\mathrm{N}=79) \\
(3)\end{array}$ & & $\begin{array}{l}\text { Interim - } \\
\text { Director } \\
\mathrm{N}=104) \\
\quad(4)\end{array}$ & $\begin{array}{l}(3) \\
\text { VS. } \\
(4)\end{array}$ \\
\hline \multicolumn{2}{|l|}{ As stated by the firm } & \multirow{2}{*}{\multicolumn{2}{|c|}{$22.66 \%$}} & \multirow[b]{2}{*}{$50.82 \%$} & \multirow{2}{*}{\multicolumn{2}{|c|}{ **** }} & \multirow{2}{*}{\multicolumn{2}{|c|}{$41.77 \%$}} & & \\
\hline Resign & & & & & & & & & $57.69 \%$ & ** \\
\hline Retire & & \multicolumn{2}{|c|}{$39.21 \%$} & $18.03 \%$ & 0 & ** & \multicolumn{2}{|c|}{$16.46 \%$} & $19.23 \%$ & \\
\hline Health Related & & \multicolumn{2}{|c|}{$1.36 \%$} & $9.29 \%$ & 0 & ** & \multicolumn{2}{|c|}{$16.46 \%$} & $3.85 \%$ & $* * *$ \\
\hline Other Explanation & & \multicolumn{2}{|c|}{$9.09 \%$} & $17.49 \%$ & & ** & \multicolumn{2}{|c|}{$20.25 \%$} & $15.38 \%$ & \\
\hline Missing Explanation & & \multicolumn{2}{|c|}{$27.68 \%$} & $4.37 \%$ & 0 & & \multicolumn{2}{|c|}{$5.06 \%$} & $3.85 \%$ & \\
\hline $\begin{array}{l}\text { Parrino (1997) } \\
\text { classification }\end{array}$ & & \multirow{2}{*}{\multicolumn{2}{|c|}{$37.04 \%$}} & $100.00 \%$ & & & $100.00 \%$ & & $100.00 \%$ & \\
\hline Forced Turnover & & & & $62.30 \%$ & 0 & & \multicolumn{2}{|c|}{$53.16 \%$} & $69.23 \%$ & $* *$ \\
\hline
\end{tabular}

Table 1 presents descriptive statistics on successor CEOs and the circumstances surrounding the CEO successions. Panel A shows the relationship between the successor CEO and the firm immediately prior to appointment as CEO. The first (last) two columns present the prior relationship between interim (permanent) CEOs and the firm. Panel B presents descriptive statistics of the predecessor and successor CEOs during the quarter of the turnover and of the firm during the quarter prior to the turnover. The first (second) column presents descriptive statistics for permanent (interim) successions. The third (fourth) column presents descriptive statistics for interim successions that resulted in the appointment of an interim CEO who was a lower-level executive (non-executive director) immediately prior to appointment. $q$ is the number of full quarters since the quarter of the turnover (e.g., $q=0$ represents the quarter of the turnover). Firm variables are winsorized at the $1^{\text {st }}$ and $99^{\text {th }}$ percentiles by $q$. Panel $\mathrm{C}$ displays the reasons for the CEO departures. The first (second) column presents the reasons for permanent (interim) successions. The third (fourth) column presents the reasons for interim successions that resulted 
in the appointment of an interim CEO who was a lower-level executive (non-executive director) immediately prior to appointment. All variables are defined in the appendix. ${ }^{*},{ }^{* *}$, and ${ }^{* * *}$ indicate statistical significance at the $10 \%, 5 \%$, and $1 \%$ level, respectively.

Table 1 Panel B presents firm and CEO characteristics surrounding the succession. Successors of interim successions, on average, are significantly older than successors of permanent successions. In particular, the average interim CEO who was a non-executive director of the firm is 61 years old, while the average permanent CEO (interim CEO who was a lower-level executive) is 53 (52) years old.

While $25 \%$ of predecessor CEOs of interim successions stay with the firm in some position, a significantly greater number $(67 \%)$ of predecessor CEOs of permanent successions stay with the firm. Furthermore, predecessor CEOs who stay with the firm following interim (permanent) successions are most likely to stay in a transitional (the chairman) position. Additionally, predecessors of interim successions are significantly younger and have shorter tenure than predecessors of permanent successions. These results suggest that interim successions are the result of unanticipated departures.

Firms with interim successions are, on average, smaller and younger than firms with permanent successions, consistent with these firms lacking successions plans (Naveen, 2006). These firms also have weaker performance prior to the turnover than firms that have permanent successions. Overall, the evidence is consistent with interim successions occurring due to unanticipated departures (e.g., turnovers due to poor firm performance) and lack of succession plans.

Table 1 Panel C presents the stated rationale for the departure of the predecessor CEO from the position. Approximately half of the firms with interim successions indicate that the predecessor 
CEO resigned. ${ }^{8}$ Further, a significantly greater percentage of firms with interim CEOs who were non-executive directors use this explanation than firms with interim CEOs who were lower-level executives. In contrast, less than a quarter of permanent successions state that the predecessor resigned. Additionally, interim successions are more likely to occur after departures related to other unanticipated departures (e.g., health issues, scandals, etc.), while a greater percentage of permanent successions are anticipated (e.g., retirement). I follow Parrino (1997) to classify turnovers as forced or voluntary. $62 \%$ of interim successions are forced turnovers, while only $37 \%$ of permanent successions are forced turnovers. ${ }^{9}$ Further, $69 \%$ (53\%) of interim successions that appoint a non-executive director (lower-level executive) as CEO are forced turnovers. These findings are consistent with a greater percentage of interim successions, particularly those that appoint a non-executive director as interim CEO, following unanticipated departures than anticipated departures.

Table 2 Panel A presents descriptive statistics on the length of the interim period. The interim period is defined as the number of days that the CEO is classified as interim. The average (median) length of the interim period is 179 (140.5) days. 78\% (34\%) of interim CEOs stay for at least 90 (180) days. Interim CEOs who eventually obtain the permanent CEO position typically have shorter interim periods. For example, only $68 \%$ of these interim CEOs have an interim period greater than 90 days, while $80 \%$ (92\%) of interim CEOs who stay with the firm in another position

\footnotetext{
${ }^{8}$ Also included in this calculation are turnovers that state variations of the following words: terminate, step down, relinquish, remove, left, relieved, ceased, and contract. $36 \%$ of interim successions explicitly state resignation, which is significantly greater than the $15 \%$ of permanent successions that explicitly state resignation.

${ }^{9}$ Parrino (1997) classifies turnovers as forced if either (1) it is stated as forced or (2) if the CEO is younger than the age of 60 years and the reason stated is not due to health, being raided, or a planned retirement. To be a planned retirement, the retirement must be announced at least six months prior to the succession. The rate of forced turnovers that I find are higher than those in Parrino (1997). However, it is similar to the percentage of CEO turnovers that are "performance-induced" found in Jenter and Lewellen (2017). Intintoli, Zhang, and Davidson (2014) use a similar definition to identify forced turnovers. They find that approximately $70 \%$ of interim successions are forced turnovers.
} 
(do not stay with the firm in any position) have an interim period greater than 90 days. Additionally, interim CEOs who were non-executive directors remain in the interim CEO position for a significantly longer period of time than interim CEOs who were lower-level executives.

Table 2: Descriptive Statistics: Tenure and Career Outcomes of Interim CEOs

Panel A: Tenure

\begin{tabular}{lr|rrr|rr}
\hline & $\begin{array}{r}\text { All } \\
\text { Interim } \\
(\mathrm{N}=183)\end{array}$ & $\begin{array}{r}\text { Not Stay } \\
(\mathrm{N}=15)\end{array}$ & $\begin{array}{r}\text { Stay - CEO } \\
(\mathrm{N}=53)\end{array}$ & $\begin{array}{r}\text { Stay-Other } \\
(\mathrm{N}=115)\end{array}$ & $\begin{array}{r}\text { Interim - } \\
\text { Lower-Level } \\
(\mathrm{N}=79)\end{array}$ & $\begin{array}{r}\text { Interim - } \\
\text { Director } \\
(\mathrm{N}=104)\end{array}$ \\
\cline { 2 - 7 } Mean & 179.56 & 271.25 & 174.00 & 172.55 & 143.95 & 206.78 \\
Median & 140.5 & 192.5 & 116 & 141 & 123 & 161 \\
$>=90$ days & $78.14 \%$ & $91.67 \%$ & $67.92 \%$ & $80.87 \%$ & $74.68 \%$ & $80.77 \%$ \\
$>=120$ days & $61.75 \%$ & $83.33 \%$ & $49.06 \%$ & $64.35 \%$ & $51.90 \%$ & $69.23 \%$ \\
$>=150$ days & $47.54 \%$ & $75.00 \%$ & $39.62 \%$ & $46.96 \%$ & $36.71 \%$ & $55.77 \%$ \\
$>=180$ days & $34.43 \%$ & $58.33 \%$ & $24.53 \%$ & $34.78 \%$ & $25.32 \%$ & $41.35 \%$ \\
$>=270$ days & $15.30 \%$ & $25.00 \%$ & $7.55 \%$ & $15.65 \%$ & $11.39 \%$ & $18.27 \%$ \\
$>=360$ days & $8.74 \%$ & $25.00 \%$ & $5.66 \%$ & $6.09 \%$ & $2.53 \%$ & $13.46 \%$ \\
\hline
\end{tabular}

Panel B: Career Outcomes following Interim Period

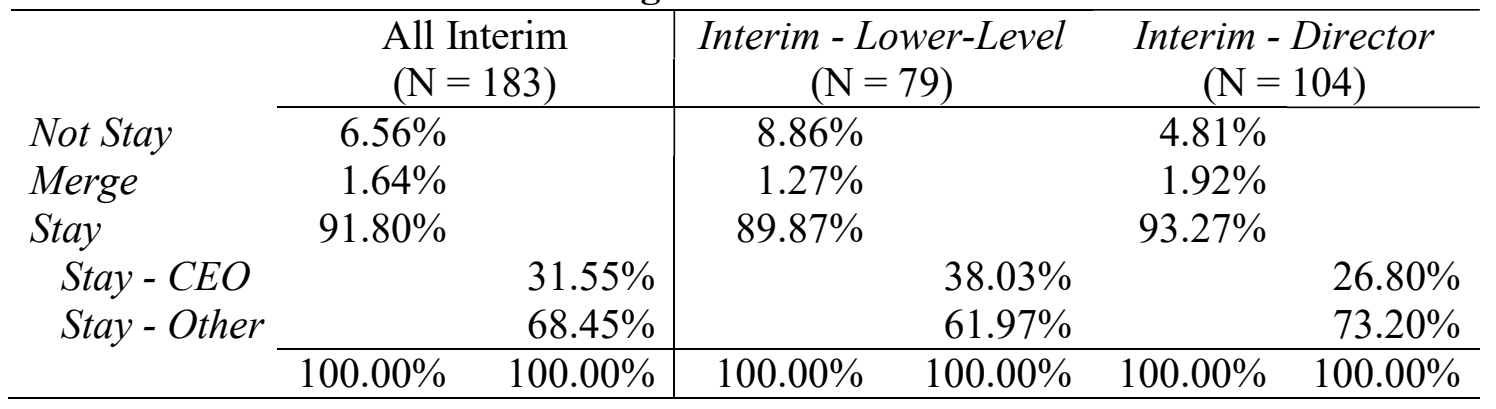

Panel C: Market reaction: Stay Announcement

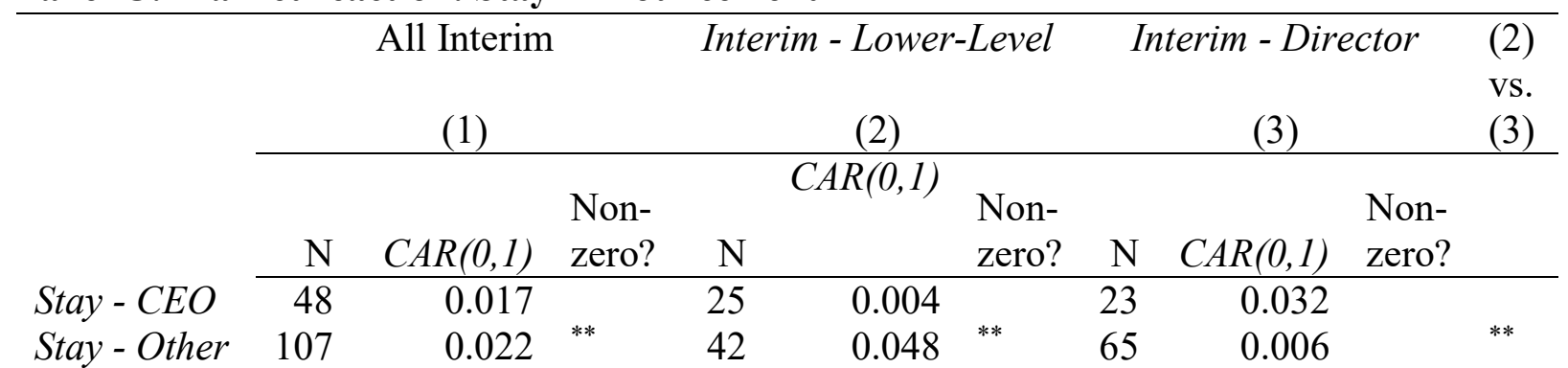

Table 2 presents descriptive statistics on the length of the interim period and the relationship between the firm and interim CEO subsequent to the interim period. Panel A shows the length of the interim period, defined as the number of days where the CEO is classified as an interim CEO. The first column presents descriptive statistics for all interim CEOs. In the next three columns, 
interim CEOs are split into three groups based on whether they leave the firm immediately following the interim period (Not Stay), stay with the firm in the CEO position (Stay - CEO), or whether they stay with the firm in a non-CEO position (Stay - Other). The last two columns present the interim periods for interim CEOs based on their relationship with the firm immediately prior to appointment. $>=\mathrm{n}$ days represents the percentage of interim periods that were at least $\mathrm{n}$ days. Panel B shows the relationship between the successor CEO and firm following the interim period. Panel $\mathrm{C}$ shows the two day market reaction to the announcement of the relationship between the interim CEO and firm following the interim period. All variables are defined in the appendix.

Table 2 Panel B presents statistics regarding the relationship between the firm and interim CEO following the interim period. Almost all (92\%) interim CEOs stay with the firm in some position following the interim period. Furthermore, close to one third of interim CEOs who stay with the firm stay as the permanent CEO. The percentage of interim CEOs who obtain the permanent $\mathrm{CEO}$ position at the current firm is greater for lower-level executives than for nonexecutive directors, but the difference is not statistically significant.

Table 2 Panel C reports the two-day cumulative abnormal returns beginning on the day of the announcement of the interim CEO either staying with the firm as the CEO or in another position. On average, the market does not react to the announcement that an interim CEO is staying in the CEO position. This finding suggests that the market expects interim CEOs to remain as CEO. On the other hand, when the firm announces that an interim CEO is returning to a non-CEO position at the firm, the market reaction is positive and significant, suggesting that the market is surprised by this announcement. Furthermore, this finding is driven by interim CEOs who were lower-level executives of the firm, suggesting that the market previously expected these interim CEOs to remain as permanent CEO. Typically the announcement of an interim CEO returning to a non-CEO position at the firm is accompanied by the announcement of the incoming permanent CEO, thus univariate analysis will be partially impacted by the characteristics of the incoming CEO. 


\section{CHAPTER 3}

\section{RELATED LITERATURE AND HYPOTHESIS DEVELOPMENT}

\subsection{CEO Successions}

Prior research suggests that CEOs have a significant impact on firm decisions and, thus, firm outcomes. Pioneering this literature, Bertrand and Schoar (2003) find evidence that acquisition and diversification decisions, dividend policies, interest coverage, and cost-cutting policies vary across managers. Subsequent studies show that individual managers also influence voluntary disclosure choices (Bamber et al., 2010; Brochet, Faurel, and McVay, 2011) and tax avoidance decisions (Dyreng et al., 2010). Based on survey data, Graham, Harvey, and Puri (2013) find that behavioral traits of CEOs are related to corporate financial policies. Relatedly, Demerjian, Lev, Lewis, and McVay (2012) document a positive association between managerial ability and earnings quality. Prior literature also finds that CEO overconfidence and optimism are positively related to investments. ${ }^{10}$

Given the key role that CEOs play, CEO successions may result in significant changes in firm-level decisions and outcomes. Consistent with this, Murphy and Zimmerman (1993) find that, after CEO successions that were preceded by poor performance, successor CEOs are more likely to exercise discretion over expenditures and discretionary accruals relative to the predecessor CEO. Perhaps because successors can blame the predecessor for poor performance, managers are also more likely to record write-downs and take large "baths" following CEO successions (Strong

\footnotetext{
${ }^{10}$ Malmendier and Tate (2005) find evidence consistent with overconfident managers overinvesting when they have internal funds available, but restricting investment when external financing is required. Campbell, Gallmeyer, Johnson, Rutherford, and Stanley (2011) show that highly optimistic CEOs overinvest. Hirshleifer, Low, and Teoh (2012) show that overconfident CEOs achieve greater innovation success. Furthermore, Schrand and Zechman (2012) find that overconfident CEOs are more likely to exhibit an optimistic bias in financial reporting, which leads to larger misstatements and AAERs.
} 
and Meyer, 1987; DeAngelo, 1988). Furthermore, Pourciau (1993) finds that CEOs are more likely to manage earnings downward in their first year and increase earnings in following years. Possibly due to poor performance, firms are more likely to downsize or divest poorly performing acquisitions following CEO successions (Denis and Denis, 1995; Weisbach, 1995). There is also evidence that indicates a significant increase in stock price volatility following CEO turnovers (Clayton, Hartzell, and Rosenberg, 2005), suggesting increased uncertainty.

Additionally, investors view successions as important events. In particular, prior studies show that shareholders react positively to CEO successions on average and negatively to raids (i.e., when the CEO leaves for a CEO position at another firm) (Hayes and Schaefer, 1999; Huson et al., 2001). Furthermore, CEO succession is among the top five discussions that boards of directors have with shareholders (Spencer Stuart, 2017), and over half of directors believe boards need to spend more time discussing CEO successions (PWC, 2016). Finally, CEO successions occur frequently and have increased in frequency from $15 \%$ of Fortune 500 firms experiencing CEO turnovers annually during the 1992-1999 period to 17\% during the 2000-2007 period (Kaplan and Minton, 2012).

In my sample, less than $80 \%$ of CEO successions result in the immediate appointment of a permanent successor; the remaining involve the appointment of an interim CEO while the board conducts a search for a permanent successor. Yet, there is little systematic evidence on the impact that interim CEO successions have on firms. Prior studies in finance and accounting typically either exclude interim successions from their analysis or include them without addressing possible differences between interim and permanent successions. ${ }^{11}$

\footnotetext{
${ }^{11}$ One exception is Hoitash and Mkrtchyan (2017) which examines the determinants and consequences of a firm's decision to appoint a director as the CEO. In additional analysis, the authors compare the market reaction of
} 


\subsection{Interim Successions}

A number of studies in management provide some preliminary evidence on interim successions. Ballinger and Marcel (2010) examine CEO successions at S\&P 1500 firms during the 1996-1998 period and find evidence of lower ROA following interim successions. This effect is moderated if the interim CEO concurrently holds the chairman position. They conclude that firms with interim successions are at a competitive disadvantage following the succession. Intintoli et al. (2014) extend the sample used by Ballinger and Marcel (2010) to include turnovers that occurred during the 1984-2007 period in S\&P 1500 firms and covered by the Wall Street Journal. They show that firms with voluntary (forced) turnovers have lower (similar) ROA following interim successions in comparison to firms with permanent successions. This leads them to suggest that not all interim successions are value decreasing, and it is important to consider the circumstances surrounding the turnover.

Mooney et al. (2014) examine the determinants of interim successions for a narrow sample (successions between 1998 and 2005 at firms in the two-digit SIC codes of 20 to 39 and with sales between $\$ 100$ million and $\$ 1$ billion) and find that firms without succession plans or where the predecessor was either forced out or had a short tenure are more likely to have interim successions. They conclude that the context of turnover and availability of human capital are important determinants of interim successions. Chen et al. (2015a) examine CEO turnovers recorded in Audit Analytics during the 2004-2008 period. ${ }^{12}$ They show that firms are more likely to manage earnings

these appointments to that of appointments of interim CEOs and find that the market reacts negatively to the appointment of interim CEOs.

${ }^{12}$ My study differs from Chen et al. (2015a) in several ways. First and foremost, I consider the variation in the incentives of interim CEOs (i.e., they do not examine aspiring interim CEOs and place-holding interim CEOs separately). Second, I examine market perception and a more comprehensive set of corporate behavior, including additional earnings management methods and management forecast characteristics (i.e., they examine only one type of corporate behavior: earnings management through accruals management). Third, because prior literature has shown 
upwards through the usage of discretionary accruals following interim successions. Furthermore, interim CEOs who manage earnings upwards are more likely to obtain the permanent CEO position. They conclude that interim CEOs actively manage their reputations to increase their likelihood of obtaining the permanent CEO position.

\subsection{Hypothesis Development}

Subsequent to CEO turnover, firms may appoint either a permanent or interim successor. ${ }^{13}$ Conventional wisdom, prior literature, and anecdotal evidence suggest that interim and permanent CEOs have different horizons. In my sample, the average interim CEO is in the position for six months. Additionally, some interim CEOs likely aspire to a permanent CEO position. However, all permanent CEOs have obtained the permanent position. This will lead interim CEOs and permanent CEOs to have different career concerns. As a result of the combination of short horizons and different career concerns, interim and permanent CEOs likely have different incentives. Furthermore, there is likely systematic variation in career concerns across interim CEOs.

The descriptive statistics in Table 1 Panel A show that nearly all interim CEOs come either from a lower-level executive position or a non-executive board position. Possibly because of the greater monetary and non-monetary benefits, the CEO position is highly desired, particularly among lower-level executives (Korn Ferry, 2014). Thus, I expect interim CEOs who were lowerlevel executives of the firm to aspire to a permanent CEO position. In contrast, interim CEOs who were non-executive directors are significantly older and closer to retirement age. Thus, I expect

\footnotetext{
that CEOs behave differently at the beginning of their tenure (Pourciau, 1993), I examine how incentives of interim CEOs influence corporate behavior differentially over each firm quarter subsequent to the turnover. Chen et al. (2015a) do not separately examine discretionary accruals for each quarter subsequent to the succession.

${ }^{13}$ This decision depends partially on the nature of the CEO turnover. For example, Mooney et al. (2014) find that interim CEOs are more likely to be appointed following forced turnovers and turnovers at firms without succession plans. My sample supports these findings. In particular, I show that a greater percentage of interim successions are the result of unanticipated departures (i.e., resignations, health issues, and scandals) relative to permanent successions.
} 
interim CEOs who were non-executive directors of the firm to be less likely to aspire to a permanent CEO position ${ }^{14}$. Additionally, the results in Table 2 Panel $\mathrm{C}$ suggest that the market expects interim CEOs who were lower-level executives of the firm to be more likely to remain as CEO than interim CEOs who were non-executive directors. While the market reaction to the announcement of an interim CEO who was a non-executive director staying as permanent CEO is not significantly different from zero $(\mathrm{t}$-stat $=1.56)$, the test may suffer from a small sample. In sum, I conjecture that there are two types of interim CEOs: those that likely aspire to a permanent CEO position (aspiring interim CEOs) and those that do not seek a permanent CEO position (placeholding interim CEOs). These different career concerns may lead to different market perceptions and CEO behavior.

In order to increase their chances of obtaining a permanent CEO position, aspiring interim CEOs will strive to develop reputations as high-quality CEOs. The labor market reassesses ability and reputation based on performance on the job (Murphy, 1986; Gibbons and Waldman, 1999). Because aspiring interim CEOs have an average of five months to show their ability, initial assessments of ability are much more important for aspiring interim CEOs than for permanent CEOs. The combination of short horizons (to allow the labor market to assess ability) and career concerns create greater incentives for aspiring interim CEOs (relative to permanent CEOs) to take actions that boost short-term performance, i.e., act myopically. In contrast (and consistent with arguments in prior literature), permanent CEOs presumably have a longer period of time to build a reputation, and, therefore, are less likely to emphasize short-term performance. As discussed

${ }^{14}$ For twenty observations, I examine additional positions that interim CEOs who were non-executive directors hold. I find that six of these interim CEOs are involved in consulting, investment, and private equity firms, six have no apparent executive position, and the remaining are either retired, hold a position at a related company, or work in higher education. 
previously, CEOs have a significant impact on firm decisions. Consistent with this, the market values individual CEOs differently. Accordingly, I expect the market to anticipate myopic behavior from aspiring CEOs. This leads to my first hypothesis:

H1: The market reacts negatively to the appointment of aspiring interim CEOs relative to permanent CEOS.

Place-holding interim CEOs have fewer incentives to develop reputations as being highquality CEOs than permanent CEOs. Rather, they may be content to return to their prior position following the interim period. Place-holding interim CEOs may also have less compensation tied to firm performance than permanent CEOs. Combined with short tenures (approximately seven months), place-holding interim CEOs have fewer incentives than permanent CEOs to exert effort while in the CEO position. Additionally, place-holding interim CEOs may be involved in the search for a permanent CEO. If so, they will have less time to devote to CEO duties than permanent CEOs. Thus, I expect the market to anticipate lower effort exerted by place-holding interim CEOs. This leads to my second hypothesis:

H2: The market reacts negatively to the appointment of place-holding interim CEOs relative to permanent CEOs. 


\section{CHAPTER 4}

\section{MARKET REACTION: RESEARCH DESIGN AND RESULTS}

\subsection{Research Design}

I begin my analysis by first examining investor perception of the appointment of interim CEOs with respect to permanent CEOs. To do this, I examine the market reaction to the succession announcement. Specifically, I estimate the following regression using Ordinary Least Squares:

$$
\text { CAR }(0,1)=\alpha+\beta_{1} \text { Interim }+\beta_{2} \text { Forced Turnover }+\beta_{3} \text { Raided Turnover }+\varepsilon
$$

$\operatorname{CAR}(0,1)$ is the cumulative abnormal returns for the firm adjusted for Fama and French (1996) and Carhart (1997) factors over the two-day window where day zero is the day the CEO succession is announced. The variable of interest, Interim, is an indicator variable that is equal to one if the firm appoints an interim CEO and zero if the firm appoints a permanent CEO. ${ }^{15}$ The market reacts differently to CEO turnovers depending on the reason for the turnover (Hayes and Schaefer, 1999), thus, I separately control for turnovers that were forced and those that were due to the predecessor being raided. Following Parrino (1997), Forced Turnover is an indicator variable that is equal to one if the succession occurred due to the forced departure of the predecessor CEO and zero otherwise. Raided Turnover is an indicator variable that is equal to one if the succession occurred due to the predecessor accepting a position at another firm and zero otherwise. All variables are defined in the appendix.

\footnotetext{
${ }^{15}$ Due to the small sample of interim CEOs who were not lower-level executives or non-executive directors of the firm immediately prior to appointment as CEO, I exclude them from analysis in the remaining portions of the paper. In untabulated results, I include them and obtain similar results, both quantitatively and qualitatively.
} 
To examine whether the market reacts differently to the appointment of aspiring interim CEOs and place-holding interim CEOs, I estimate the following regression using Ordinary Least Squares:

$$
\begin{gathered}
\text { CAR }(0,1)=\alpha+\beta_{1} \text { Aspiring }+\beta_{2} \text { Place-holding }+\beta_{3} \text { Forced Turnover } \\
+\beta_{4} \text { Raided Turnover }+\varepsilon
\end{gathered}
$$

For this equation, I replace the variable of interest from Equation (1), Interim, with two variables that indicate the type of interim CEO: Aspiring and Place-holding. Aspiring is an indicator variable set equal to one if the interim $\mathrm{CEO}$ was previously a lower-level executive for the firm and zero otherwise. Place-holding is an indicator variable set equal to one if the interim CEO was previously a non-executive director of the firm and zero otherwise. All other variables are defined as in Equation (1) and in the appendix.

Under H1, the market anticipates myopic behavior from aspiring CEOs, as such, I expect $\beta_{1}<0$. Under $\mathrm{H} 2$, the market anticipates lower effort from place-holding CEOs, thus I expect $\beta_{2}<$ 0 .

\subsection{Results}

Table 3 presents the results for Equations (1) and (2). Consistent with investors anticipating unfavorable CEO behavior from interim CEOs, the coefficient on Interim is negative and significant. However, in Column (2) when estimating Equation (2), I show that this result is driven by place-holding interim CEOs. This is consistent with investors perceiving place-holding interim CEOs as exerting less effort than permanent CEOs (i.e., H2). On the other hand, the market reacts similarly to the appointment of aspiring interim CEOs as it does to permanent CEOs. This result is inconsistent with investors perceiving the appointment of these interim CEOs as bad news and 
aspiring interim CEOs acting myopically (i.e., H1). Furthermore, the market reacts significantly more negative to the appointment of place-holding interim CEOs than aspiring interim CEOs. This result suggests that the market perceives place-holding interim CEOs as greater concern than aspiring interim CEOs. This provides initial evidence of firm outcomes being dependent on the career concerns of interim CEOs.

Table 3: Market reaction: CEO appointments



Table 3 presents results for multivariate regressions using Ordinary Least Squares to examine the two-day market reaction to the announcement of the CEO succession. All variables are defined in the appendix. t-stats are reported in parentheses. ${ }^{*},{ }^{* *}$, and ${ }^{* * *}$ indicate statistical significance at the $10 \%, 5 \%$, and $1 \%$ level, respectively.

In Column (3) of Table 3, I control for the prior relationship between the firm and successor immediately prior to appointment as CEO. I find that, on average, the market reaction to the appointment of lower-level executives as CEO is negative and significant. However, the market 
reacts similarly to the appointment of external CEOs as it does to the appointment of non-executive directors as CEOs. The findings from the previous columns remain unchanged, suggesting that the negative market reaction to the appointment of place-holding interim CEOs is a result of nonexecutive directors becoming interim CEO. The remaining portion of the paper examines whether market expectations of the two types of interim CEOs are in line with CEO behavior. 


\section{CHAPTER 5}

\section{CEO BEHAVIOR: RESEARCH DESIGN AND RESULTS}

\subsection{Myopic Behavior}

I next examine directly whether aspiring interim CEOs act more myopically than permanent CEOs. Theory predicts that myopic executives will manage current earnings (Stein, 1988, 1989; Shleifer and Vishny, 1990). Thus, I proxy for myopic behavior with earnings management, both through accruals and real activities management. Prior research documents that executives strategically adjust discretionary accruals in order to increase current performance (for review of literature see Healy and Wahlen [1999] and Dechow et al. [2010]). Pioneering this literature, Jones (1991) finds that managers decrease earnings by manipulating accruals during import relief investigations. Additional papers have found that managers adjust discretionary accruals during seasoned equity offerings, initial public offerings, and management buyout offerings to increase current earnings (Perry and Williams, 1994; Teoh, Welch, and Wong, 1998; DuCharme, Malatesta, and Sefcik, 2001). Consistent with interim CEOs, on average, acting myopically, Chen et al. (2015a) find that interim CEOs use discretionary accruals to manage earnings upwards.

Empirical evidence shows that myopic executives are more likely to manipulate real activities, such as reducing R\&D activities (Dechow and Sloan, 1991; Chen et al., 2015b). Roychowdhury (2006) finds that executives manipulate real activities to avoid reporting losses. To do this, they may increase sales by offering price discounts, lower cost of goods sold by overproducing, and improve margins by reducing discretionary expenses, such as research and development. Other studies document that managers engage in real activities management to meet or beat earnings benchmarks (Bhojraj, Hribar, Picconi, and McInnis, 2009; Gunny, 2010). Cohen 
and Zarowin (2010) show that managers engage in real activities management prior to seasoned equity offering. In a survey by Graham, Harvey, and Rajgopal (2005), executives acknowledge that they engage in real activities management and that they would prefer to manage real activities rather than accruals, perhaps because costs associated with accruals management are greater than costs associated with real activities management.

\subsubsection{Measurement of key variables}

Proxies for accruals management

I rely on two accruals management proxies: discretionary accruals based on the modified Jones (1991) model (Dechow, Sloan, and Sweeney, 1995) and performance-matched accruals (Kothari, Leone, and Wasley, 2005). I begin by calculating discretionary accruals. I define total accruals using the statement of cash flows method, following Hribar and Collins (2002). Because the interim period for most firms is less than one year, I examine myopic behavior on a quarterly basis. Using all firms in the Compustat universe, I first estimate the following regression for each year, fiscal quarter, and industry (based on two-digit SIC codes) using Ordinary Least Squares:

$$
T A C C=\alpha+\beta_{1} \frac{1}{\operatorname{avgATQ}}+\beta_{2} \frac{(S A L E Q-\operatorname{lag} S A L E Q)}{\operatorname{avg} A T Q}+\beta_{3} \frac{P P E G T Q}{\operatorname{avg} A T Q}+\varepsilon
$$

TACC is the difference between income before extraordinary items and cash flows of continuing operations less extraordinary items and discontinued operations scaled by average assets during the quarter $(\operatorname{avg} A T Q)$. $S A L E Q$ (lagSale $Q)$ is sales for the current (previous) quarter. PPEGTQ is gross property, plant, and equipment at the end of the current period. Additionally, to ensure that Equation (3) represents a broad sample (rather than just a few firms), I require that each year, quarter, and industry have at least ten observations. Using the estimated coefficients from 
Equation (3), I calculate non-discretionary accruals for each firm-quarter. ${ }^{16}$ Discretionary accruals is the difference between TACC and non-discretionary accruals. All variables are defined in the appendix.

Because firms with interim successions have significantly lower performance than firms with permanent successions prior to and subsequent to the turnover (Ballinger and Marcel, 2010), I also calculate performance matched discretionary accruals. Following Kothari et al. (2005), I use Discretionary accruals as calculated above. I then match each observation in my sample to a firm in the same industry with a permanent succession with the most similar firm performance, measured by return on assets. ${ }^{17}$ I then calculate performance matched discretionary accruals (Performance-matched DACC) as the difference between Discretionary accruals of the firm and Discretionary accruals of the performance-matched firm.

\section{Proxy for real activities management}

Roychowdhury (2005) proxies for real activities management in three ways. His first proxy is abnormal cash flows from operations. This proxies for sales management, such as price discounts and/or more lenient credit terms. The second proxy, abnormal production costs, represents overproduction by a firm. To increase current earnings, firms may decrease cost of goods sold by overproducing goods. Lastly, abnormal discretionary expenses, such as research and development (R\&D) and selling, general, and administrative (SG\&A) proxy for a firm's ability to reduce these expenses in the current period, effectively increasing current performance. However, Kothari, Mizik, and Roychowdhury (2016) argue that the first two strategies are not ideal to

\footnotetext{
${ }^{16}$ A significant portion of my sample does not report gross property, plant, and equipment (PPEGTQ) on a quarterly basis. This results in significant sample attrition for tests that use accruals.

${ }^{17}$ I require that the absolute difference between ROA not be greater than $10 \%$.
} 
examine since engaging in these two strategies to increase current earnings has a negative impact on profit margins and cash flows from operations, which managers and investors may value. ${ }^{18}$

Thus, my proxy for real activities management is abnormal discretionary expenses, following Roychowdhury (2005). Because the interim period for most firms is less than one year, I examine myopic behavior on a quarterly basis. Using all firms in the Compustat universe, I estimate the following regression for each year, fiscal quarter, and industry (based on two-digit SIC codes) using Ordinary Least Squares:

$$
D I S X=\alpha+\beta_{1} \frac{1}{\operatorname{avg} A T Q}+\beta_{2} \frac{\operatorname{lag} S A L E Q}{\operatorname{avg} A T Q}+\varepsilon
$$

$D I S X$ is the sum of research and development expense and selling, general and administrative expenses scaled by average assets during the quarter (avgATQ). lagSALEQ is sales during the previous quarter. All variables are defined in the appendix. Additionally, to ensure that Equation (4) represents a broad sample (rather than just a few firms), I require that each year, quarter, and industry have at least ten observations. I use the estimated coefficients from Equation (4) to calculate normal discretionary expenses for each firm-quarter observation. The proxy for real activities management, abnormal discretionary expenses (Discretionary expenses), is the difference between DISX and normal discretionary expenses.

\subsubsection{Research design}

Before examining myopic behavior by aspiring interim CEOs, I first examine whether interim CEOs, on average, engage in myopic behavior more than permanent CEOs. Firms behave

\footnotetext{
${ }^{18}$ However, increasing production may be seen as a strong signal. In un-tabulated results, I use these two proxies. I find that there is no significant differences in these proxies between firms with interim CEOs and those with permanent CEOs.
} 
differently the first period following turnovers (Pourciau, 1993). Thus, I separately examine the effect for each quarter, starting with the quarter of the turnover $(q=0)$, and require that the CEO be present at the end of the quarter. Specifically, I estimate the following equation using Ordinary Least Squares:

$$
\begin{aligned}
\text { EM }_{q}= & \alpha+\beta_{1} \text { Interim }+\beta_{2} \text { Forced Turnover }+\beta_{3} E M_{q-4}+\beta_{4} \text { Firm Size }_{q}+B_{5} \text { ROA }_{q} \\
& +\beta_{6} \text { ROA }_{q}{ }^{2}+\beta_{7} \text { BTM }_{q}+\beta_{8} \text { Firm Age }_{q}+\beta_{9} \text { Leverage }_{q}+\lambda \text { Industry fixed effects } \\
& +\delta \text { Year/Quarter fixed effects }+\varepsilon
\end{aligned}
$$

The dependent variable, $E M$, is set equal to the three proxies of earnings management: discretionary accruals (Discretionary accruals), performance-matched discretionary accruals (Performance-matched DACC), and discretionary expenses (Discretionary expenses), as defined in Section 5.1.1. All variables are defined in the appendix. The variable of interest, Interim, is an indicator variable that is equal to one if the firm has an interim CEO in quarter $q$ and zero if the firm has a permanent CEO in quarter $q$. If interim CEOs, on average, are more myopic than permanent CEOs, then the coefficient of Interim will be positive, $\beta_{2}>0$, when the dependent variable is one of the proxies for accruals management, Discretionary accruals and Performancematched $D A C C$. In contrast, the coefficient of Interim will be negative, $\beta_{2}<0$, when the dependent variable is Discretionary expenses.

I include several control variables that have been shown to be related to proxies for earnings management as well as differences between firms with interim CEOs and firms with permanent CEOs. Interim successions are more likely to occur following forced turnovers. Following Parrino (1997), Forced Turnover is an indicator variable that is equal to one if the succession occurred due to the forced departure of the predecessor CEO and zero otherwise. 
Larger firms typically have higher abnormal discretionary expenses (Roychowdhury, 2005; Cohen, Dey, and Lys, 2008). Additionally, firms with interim successions are significantly smaller than firms with permanent successions. Thus, I control for firm size (Firm Size), calculated as the natural $\log$ of the market capitalization of the firm at the end of the quarter. Firms with better performance have lower discretionary expenses and greater abnormal discretionary accruals (Dechow et al., 1995; Roychowdhury, 2006). Furthermore, as shown in Table 1, Panel B, firms with interim successions have worse performance than firms with permanent successions. I measure firm performance $(R O A)$ as income before extraordinary items divided by average assets during the quarter. Because there is a non-linear relationship between $R O A$ and $E M$, I also include $R O A^{2}$. Since I have matched observations based on performance, I exclude $R O A$ and $R O A^{2}$ when examining Performance-matched DACC. Firms with permanent successions have greater growth, proxied by the book-to-market ratio $(B T M)$. Growth has also been shown to be related to likelihood of engaging in earnings management (Roychowdhury, 2006). Firms with interim successions are significantly younger than firms with permanent successions. Thus, I control for age of the firm (Firm Age). Prior literature has found that there is a relation between debt contracts/covenants and firm decisions (Fields Lys, and Vincent, 2001; Cohen and Zarowin, 2010). I proxy for this with Leverage.

I winsorize all continuous control variables at the $1^{\text {st }}$ and $99^{\text {th }}$ percentile by $q$ to reduce the effect of extreme observations. ${ }^{19}$ I include industry and year/quarter fixed effects to control for industry wide and time effects on earnings management. I define industry using two digit SIC codes. All variables are defined in the appendix.

\footnotetext{
${ }^{19}$ As discussed in Section 3.1, following CEO successions, firm behavior changes. Thus, I identify the quarter of the turnover $(q=0)$, the quarter following the turnover $(q=1)$, etc. I then winsorize by values of $q$.
} 
To test H1, whether aspiring interim CEOs act more myopically than permanent CEOs, I estimate the following equation using Ordinary Least Squares:

$$
\begin{aligned}
\text { EM }_{q}= & \alpha+\beta_{1} \text { Aspiring }+\beta_{2} \text { Place-holding }+\beta_{3} \text { Forced Turnover }+\beta_{4} E M_{q-4}+\beta_{5} \text { Firm Size }_{q} \\
& +B_{6} \text { ROA }_{q}+B_{7} \text { ROA }_{q}{ }^{2}+\beta_{8} \text { BTM }_{q}+\beta_{9} \text { Firm Age }_{q}+\beta_{10} \text { Leverage }_{q} \\
& +\lambda \text { Industry fixed effects }+\delta \text { Year/Quarter fixed effects }+\varepsilon
\end{aligned}
$$

For this model, I replace the variable of interest from Equation (5), Interim, with two variables that indicate the type of interim CEO: Aspiring and Place-holding. Aspiring is an indicator variable set equal to one if the interim CEO was previously a lower-level executive for the firm and zero otherwise. Place-holding is an indicator variable set equal to one if the interim CEO was previously a non-executive director of the firm and zero otherwise. All other variables are defined as in Equation (5) and the appendix. Under H3, I expect the coefficient of Aspiring to be positive, $\beta_{1}>0$, when the dependent variable is one of the proxies for accruals management, Discretionary accruals and Performance-match DACC. In contrast, I expect the coefficient of Aspiring to be negative, $\beta_{1}<0$, when the dependent variable is Discretionary expenses.

\subsubsection{Results}

Table 4 presents the results for Equations (5) and (6) when EM is proxied by discretionary accruals (Discretionary accruals). Firms with interim CEOs have significantly lower discretionary accruals during the first full quarter following the turnover than firms with permanent CEOs, suggesting that interim CEOs, on average, are less likely to manage earnings upwards through discretionary accruals. Next, I examine the relation between the type of interim CEO and discretionary accruals. I find that there is no significant relation between aspiring interim CEO and discretionary accruals. Additionally, there is no indication that place-holding interim CEOs 
manage accruals differently than permanent CEOs or aspiring interim CEOs. In Table 5, when examining performance-matched discretionary accruals, I do not find a significant relation between interim CEOs and earnings management during the first full quarter. However, in Columns (5) and (6), there is a negative and significant relation between Aspiring and Performance-matched $D A C C$. This suggests that aspiring interim CEOs have lower discretionary accruals during their first and second full quarters than permanent CEOs, which is inconsistent with these firms managing earnings upwards. Thus far, there is no evidence of aspiring interim CEOs engaging in myopic behavior (H1). 
Table 4: Accruals Management - Discretionary Accruals

\begin{tabular}{|c|c|c|c|c|c|c|c|c|c|}
\hline & \multicolumn{9}{|c|}{ Dependent Variable: Discretionary Accruals } \\
\hline & $\begin{array}{l}\mathrm{q}=0 \\
(1)\end{array}$ & & $\begin{array}{l}q=1 \\
(2)\end{array}$ & & $\begin{array}{l}\mathrm{q}=2 \\
(3)\end{array}$ & $\begin{array}{l}q=0 \\
(4)\end{array}$ & & $\begin{array}{l}q=1 \\
(5)\end{array}$ & $\begin{array}{l}q=2 \\
(6)\end{array}$ \\
\hline Interim & $\begin{array}{l}0.019 \\
(0.40)\end{array}$ & & $\begin{array}{l}-0.084 \\
(-2.04)\end{array}$ & & $\begin{array}{l}-0.018 \\
(-0.35)\end{array}$ & & & & \\
\hline Aspiring & & & & & & $\begin{array}{l}0.057 \\
(0.61)\end{array}$ & & $\begin{array}{l}-0.092 \\
(-1.59)\end{array}$ & $\begin{array}{l}-0.026 \\
(-0.30)\end{array}$ \\
\hline Place-holding & & & & & & $\begin{array}{l}-0.005 \\
(-0.09)\end{array}$ & & $\begin{array}{l}-0.079 \\
(-1.55)\end{array}$ & $\begin{array}{l}-0.010 \\
(-0.17)\end{array}$ \\
\hline Forced Turnover & $\begin{array}{l}-0.041 \\
(-1.09)\end{array}$ & & $\begin{array}{r}0.045 \\
(1.45)\end{array}$ & & $\begin{array}{l}0.022 \\
(0.60)\end{array}$ & $\begin{array}{l}-0.039 \\
(-1.01)\end{array}$ & & $\begin{array}{l}0.045 \\
(1.47)\end{array}$ & $\begin{array}{l}0.022 \\
(0.60)\end{array}$ \\
\hline Discretionary Accruals $_{t-4}$ & $\begin{array}{r}0.067 \\
(0.93)\end{array}$ & & $\begin{array}{l}-0.018 \\
(-0.36)\end{array}$ & & $\begin{array}{c}0.118 \\
(1.03)\end{array}$ & $\begin{array}{r}0.070 \\
(0.95)\end{array}$ & & $\begin{array}{r}-0.018 \\
(-0.36)\end{array}$ & $\begin{array}{r}0.118 \\
(1.02)\end{array}$ \\
\hline Firm Size & $\begin{array}{l}0.008 \\
(0.51)\end{array}$ & & $\begin{array}{l}-0.010 \\
(-1.05)\end{array}$ & & $\begin{array}{c}0.001 \\
(0.10)\end{array}$ & $\begin{array}{l}0.008 \\
(0.49)\end{array}$ & & $\begin{array}{l}-0.010 \\
(-1.06)\end{array}$ & $\begin{array}{c}0.001 \\
(0.10)\end{array}$ \\
\hline$R O A$ & $\begin{array}{l}-1.156 \\
(-1.45)\end{array}$ & & $\begin{array}{l}0.647 \\
(1.12)\end{array}$ & & $\begin{array}{c}0.864 \\
(1.20)\end{array}$ & $\begin{array}{l}-1.158 \\
(-1.46)\end{array}$ & & $\begin{array}{l}0.648 \\
(1.12)\end{array}$ & $\begin{array}{r}0.866 \\
(1.20)\end{array}$ \\
\hline$R O A^{2}$ & $\begin{array}{r}-10.851 \\
(-2.42)\end{array}$ & $* *$ & $\begin{array}{l}-2.927 \\
(-0.55)\end{array}$ & & $\begin{array}{r}5.380 \\
(0.85)\end{array}$ & $\begin{array}{r}-11.125 \\
(-2.39)\end{array}$ & $* *$ & $\begin{array}{l}-2.902 \\
(-0.54)\end{array}$ & $\begin{array}{l}5.405 \\
(0.85)\end{array}$ \\
\hline BTM & $\begin{array}{l}-0.008 \\
(-0.25)\end{array}$ & & $\begin{array}{l}-0.016 \\
(-1.21)\end{array}$ & & $\begin{array}{l}-0.002 \\
(-0.19)\end{array}$ & $\begin{array}{l}-0.009 \\
(-0.25)\end{array}$ & & $\begin{array}{l}-0.016 \\
(-1.21)\end{array}$ & $\begin{array}{l}-0.002 \\
(-0.19)\end{array}$ \\
\hline Firm Age & $\begin{array}{r}-0.030 \\
(-0.73)\end{array}$ & & $\begin{array}{r}0.008 \\
(0.30)\end{array}$ & & $\begin{array}{l}-0.017 \\
(-0.47)\end{array}$ & $\begin{array}{l}-0.031 \\
(-0.78)\end{array}$ & & $\begin{array}{l}0.008 \\
(0.30)\end{array}$ & $\begin{array}{l}-0.017 \\
(-0.47)\end{array}$ \\
\hline Leverage & $\begin{array}{r}0.017 \\
(0.17)\end{array}$ & & $\begin{array}{c}0.086 \\
(1.07)\end{array}$ & & $\begin{array}{r}-0.016 \\
(-0.16)\end{array}$ & $\begin{array}{r}0.025 \\
(0.25)\end{array}$ & & $\begin{array}{l}0.085 \\
(1.04)\end{array}$ & $\begin{array}{l}-0.017 \\
(-0.17)\end{array}$ \\
\hline Intercept & $\begin{array}{l}0.014 \\
(0.11)\end{array}$ & & $\begin{array}{r}0.093 \\
(1.70)\end{array}$ & * & $\begin{array}{l}-0.093 \\
(-0.57)\end{array}$ & $\begin{array}{l}0.014 \\
(0.11)\end{array}$ & & $\begin{array}{l}0.094 \\
(1.74)\end{array}$ & $\begin{array}{l}-0.101 \\
(-0.66)\end{array}$ \\
\hline Industry Fixed Effects & Yes & & Yes & & Yes & Yes & & Yes & Yes \\
\hline Year/Quarter Fixed Effects & Yes & & Yes & & Yes & Yes & & Yes & Yes \\
\hline $\mathrm{R}^{2}$ & $39.0 \%$ & & $30.2 \%$ & & $32.3 \%$ & $39.1 \%$ & & $30.2 \%$ & $32.3 \%$ \\
\hline $\mathrm{N}$ & 444 & & 412 & & 403 & 444 & & 412 & 403 \\
\hline $\mathrm{N}($ Interim $)$ & 80 & & 47 & & 18 & 80 & & 47 & 18 \\
\hline N(Aspiring) & 30 & & 18 & & 8 & 30 & & 18 & 8 \\
\hline $\mathrm{N}($ Place-holding $)$ & 50 & & 29 & & 10 & 50 & & 29 & 10 \\
\hline $\begin{array}{l}\text { Aspiring vs. Place-holding } \\
\text { Prob }>\text { F }\end{array}$ & & & & & & $\begin{array}{r}0.062 \\
(.5849)\end{array}$ & & $\begin{array}{r}-0.013 \\
(0.8551)\end{array}$ & $\begin{array}{r}-0.016 \\
(0.8709)\end{array}$ \\
\hline
\end{tabular}

Table 4 shows the results of multivariate regressions using Ordinary Least Squares to examine the relation between discretionary accruals and interim CEOs. Columns 4-6 show the relation between discretionary accruals and the type of interim CEO. $q$ is the number of full quarters since the quarter of the turnover (e.g., $q=0$ represents the quarter of the turnover). Variables are defined in the appendix. The dependent variable (Discretionary accruals) is truncated at the $1^{\text {st }}$ and $99^{\text {th }}$ percentiles by $q$. All continuous independent variables are winsorized at the $1^{\text {st }}$ and $99^{\text {th }}$ percentiles by $q$. Year/quarter and industry (defined by two digit SIC codes) fixed effects are included in regressions. Standard errors have been clustered by firm. t-stats are reported in parentheses. ${ }^{*},{ }^{* *}$, and ${ }^{* * *}$ indicate statistical significance at the $10 \%, 5 \%$, and $1 \%$ level, respectively. 
Table 5: Accruals Management - Performance-Matched Discretionary Accruals

\begin{tabular}{|c|c|c|c|c|c|c|c|c|c|c|}
\hline & \multicolumn{10}{|c|}{ Dependent Variable: Performance-Matched DACC } \\
\hline & $\begin{array}{l}\mathrm{q}=0 \\
(1)\end{array}$ & $\begin{array}{l}q=1 \\
(2)\end{array}$ & & $\begin{array}{l}\mathrm{q}=2 \\
(3)\end{array}$ & & $\begin{array}{l}\mathrm{q}=0 \\
(4)\end{array}$ & $\begin{array}{l}\mathrm{q}=1 \\
(5)\end{array}$ & & $\begin{array}{l}q=2 \\
(6)\end{array}$ & \\
\hline Interim & $\begin{array}{l}0.026 \\
(0.40)\end{array}$ & $\begin{array}{l}-0.096 \\
(-1.45)\end{array}$ & & $\begin{array}{l}-0.112 \\
(-1.60)\end{array}$ & & & & & & \\
\hline Aspiring & & & & & & $\begin{array}{r}0.038 \\
(0.47)\end{array}$ & $\begin{array}{l}-0.228 \\
(-1.84)\end{array}$ & $*$ & $\begin{array}{l}-0.173 \\
(-1.84)\end{array}$ & * \\
\hline Place-holding & & & & & & $\begin{array}{l}0.018 \\
(0.24)\end{array}$ & $\begin{array}{l}-0.017 \\
(-0.33)\end{array}$ & & $\begin{array}{l}-0.058 \\
(-0.81)\end{array}$ & \\
\hline Forced Turnover & $\begin{array}{l}0.023 \\
(0.68)\end{array}$ & $\begin{array}{r}0.039 \\
(0.67)\end{array}$ & & $\begin{array}{r}0.038 \\
(0.83)\end{array}$ & & $\begin{array}{l}0.023 \\
(0.69)\end{array}$ & $\begin{array}{r}0.030 \\
(0.53)\end{array}$ & & $\begin{array}{r}0.040 \\
(0.86)\end{array}$ & \\
\hline Performance-Matched $D A C C_{t-4}$ & $\begin{array}{l}-0.148 \\
(-0.95)\end{array}$ & $\begin{array}{l}-0.116 \\
(-1.56)\end{array}$ & & $\begin{array}{l}-0.071 \\
(-0.49)\end{array}$ & & $\begin{array}{l}-0.150 \\
(-0.95)\end{array}$ & $\begin{array}{l}-0.122 \\
(-1.62)\end{array}$ & & $\begin{array}{l}-0.071 \\
(-0.49)\end{array}$ & \\
\hline Firm Size & $\begin{array}{l}-0.002 \\
(-0.22)\end{array}$ & $\begin{array}{l}-0.009 \\
(-0.91)\end{array}$ & & $\begin{array}{r}0.023 \\
(1.74)\end{array}$ & * & $\begin{array}{l}-0.002 \\
(-0.22)\end{array}$ & $\begin{array}{l}-0.011 \\
(-1.10)\end{array}$ & & $\begin{array}{r}0.023 \\
(1.72)\end{array}$ & * \\
\hline BTM & $\begin{array}{l}-0.001 \\
(-0.05)\end{array}$ & $\begin{array}{l}-0.009 \\
(-0.47)\end{array}$ & & $\begin{array}{l}-0.002 \\
(-0.18)\end{array}$ & & $\begin{array}{l}-0.001 \\
(-0.06)\end{array}$ & $\begin{array}{l}-0.007 \\
(-0.34)\end{array}$ & & $\begin{array}{l}-0.002 \\
(-0.19)\end{array}$ & \\
\hline Firm Age & $\begin{array}{l}-0.008 \\
(-0.22)\end{array}$ & $\begin{array}{r}0.050 \\
(1.08)\end{array}$ & & $\begin{array}{l}-0.005 \\
(-0.15)\end{array}$ & & $\begin{array}{l}-0.008 \\
(-0.22)\end{array}$ & $\begin{array}{l}0.051 \\
(1.16)\end{array}$ & & $\begin{array}{l}-0.005 \\
(-0.15)\end{array}$ & \\
\hline Leverage & $\begin{array}{r}0.122 \\
(1.65)\end{array}$ & $\begin{array}{r}0.060 \\
(0.52)\end{array}$ & & $\begin{array}{r}0.017 \\
(0.16)\end{array}$ & & $\begin{array}{r}0.123 \\
(1.64)\end{array}$ & $\begin{array}{r}0.032 \\
(0.31)\end{array}$ & & $\begin{array}{r}0.009 \\
(0.09)\end{array}$ & \\
\hline Intercept & $\begin{array}{l}-0.058 \\
(-0.37)\end{array}$ & $\begin{array}{l}-0.612 \\
(-3.78)\end{array}$ & $* * *$ & $\begin{array}{l}-0.607 \\
(-1.78)\end{array}$ & * & $\begin{array}{l}-0.071 \\
(-0.42)\end{array}$ & $\begin{array}{l}-0.606 \\
(-3.87)\end{array}$ & $* * *$ & $\begin{array}{l}-0.604 \\
(-1.77)\end{array}$ & * \\
\hline Industry Fixed Effects & Yes & Yes & & Yes & & Yes & Yes & & Yes & \\
\hline $\begin{array}{l}\text { Year/Quarter Fixed Effects } \\
\mathrm{R}^{2}\end{array}$ & $\begin{array}{r}\text { Yes } \\
33.4 \%\end{array}$ & $\begin{array}{r}\text { Yes } \\
43.7 \%\end{array}$ & & $\begin{array}{r}\text { Yes } \\
29.2 \%\end{array}$ & & $\begin{array}{r}\text { Yes } \\
33.5 \%\end{array}$ & $\begin{array}{r}\text { Yes } \\
45.7 \%\end{array}$ & & $\begin{array}{r}\text { Yes } \\
29.4 \%\end{array}$ & \\
\hline $\mathrm{N}$ & 268 & 225 & & 274 & & 268 & 225 & & 274 & \\
\hline $\mathrm{N}($ Interim $)$ & 50 & 29 & & 13 & & 50 & 29 & & 13 & \\
\hline $\mathrm{N}($ Aspiring $)$ & 19 & 10 & & 6 & & 19 & 10 & & 6 & \\
\hline N(Place-holding $)$ & 31 & 19 & & 7 & & 31 & 19 & & 7 & \\
\hline $\begin{array}{l}\text { Aspiring vs. Place-holding } \\
\text { Prob > F }\end{array}$ & & & & & & $\begin{array}{r}0.02 \\
0.2646\end{array}$ & $\begin{array}{l}-0.211 \\
0.1044\end{array}$ & & $\begin{array}{l}-0.115 \\
0.8285\end{array}$ & \\
\hline
\end{tabular}

Table 5 shows the results of a multivariate regression using Ordinary Least Squares to examine the relation between performance-matched discretionary accruals and interim CEOs. Columns 46 show the relation between performance-matched discretionary accruals and the type of interim CEO. $q$ is the number of full quarters since the quarter of the turnover (e.g., $q=0$ represents the quarter of the turnover). Variables are defined in the appendix. The dependent variable (Performance-matched DACC) is truncated at the $1^{\text {st }}$ and $99^{\text {th }}$ percentiles by $q$. All continuous independent variables are winsorized at the $1^{\text {st }}$ and $99^{\text {th }}$ percentiles by $q$. Year/quarter and industry (defined by two digit SIC codes) fixed effects are included in regressions. Standard errors have been clustered by firm. t-stats are reported in parentheses. ${ }^{*},{ }^{* *}$, and ${ }^{* * *}$ indicate statistical significance at the $10 \%, 5 \%$, and $1 \%$ level, respectively.

In Table 6 the dependent variable of Equations (5) and (6) is abnormal discretionary expenses (Discretionary expenses). The coefficient on Interim is positive and significant in the quarters subsequent to the turnover, indicating that firms with interim CEOs have greater abnormal discretionary expenses subsequent to the turnover than firms with permanent CEOs. Specifically, 
in their first (second) full quarter, interim CEOs have 4.3\% (3.9\%) higher abnormal discretionary expenses than permanent CEOs. In Columns 4-6, I find that this relation is driven by aspiring interim CEOs. In particular, firms with aspiring interim CEOs have 6.6\% higher abnormal discretionary expenses than firms with permanent CEOs during the first full quarter subsequent to turnover. These results are not consistent with my third hypothesis that aspiring interim CEOs manage earnings upwards. Rather, they suggest that aspiring interim CEOs are quicker to make changes to firm operations and policies that result in increases in discretionary expenses. Placeholding interim CEOs do not appear to manage earnings significantly different than permanent CEOs or aspiring interim CEOs. There is also evidence that smaller firms, undervalued firms, and firms with lower leverage have higher abnormal discretionary expenses. 
Table 6: Real Activities Management: Abnormal Discretionary Expenses

\begin{tabular}{|c|c|c|c|c|c|c|c|c|c|c|c|}
\hline & & & & pend & ent Variable: & iscretion & $\operatorname{ary} E$ & xpenses & & & \\
\hline & $\begin{array}{l}\mathrm{q}=0 \\
(1)\end{array}$ & & $\begin{array}{l}\mathrm{q}=1 \\
(2)\end{array}$ & & $\begin{array}{l}\mathrm{q}=2 \\
(3)\end{array}$ & $\begin{array}{l}\mathrm{q}=0 \\
(4)\end{array}$ & & $\begin{array}{l}\mathrm{q}=1 \\
(5)\end{array}$ & & $\begin{array}{c}\mathrm{q}=2 \\
(6)\end{array}$ & \\
\hline Interim & $\begin{array}{c}0.013 \\
(1.12)\end{array}$ & & $\begin{array}{l}0.043 \\
(1.67)\end{array}$ & & $\begin{array}{l}0.039 \\
(1.93)\end{array}$ & & & & & & \\
\hline Aspiring & & & & & & $\begin{array}{l}0.012 \\
(0.73)\end{array}$ & & $\begin{array}{l}0.065 \\
(2.41)\end{array}$ & ** & $\begin{array}{c}0.038 \\
(1.39)\end{array}$ & \\
\hline Place-holding & & & & & & $\begin{array}{l}0.014 \\
(0.96)\end{array}$ & & $\begin{array}{r}0.029 \\
(0.87)\end{array}$ & & $\begin{array}{r}0.039 \\
(1.59)\end{array}$ & \\
\hline Forced Turnover & $\begin{array}{l}0.001 \\
(0.10)\end{array}$ & & $\begin{array}{c}-0.008 \\
(-0.73)\end{array}$ & & $\begin{array}{l}-0.016 \\
(-1.20)\end{array}$ & $\begin{array}{l}0.001 \\
(0.10)\end{array}$ & & $\begin{array}{l}-0.007 \\
(-0.68)\end{array}$ & & $\begin{array}{l}-0.016 \\
(-1.19)\end{array}$ & \\
\hline Discretionary Expenses $t-4$ & $\begin{array}{c}0.129 \\
(1.67)\end{array}$ & * & $\begin{array}{c}0.184 \\
(1.70)\end{array}$ & * & $\begin{array}{l}0.184^{* * *} \\
(3.01)^{*}\end{array}$ & $\begin{array}{l}0.129 \\
(1.67)\end{array}$ & * & $\begin{array}{l}0.181 \\
(1.68)\end{array}$ & * & $\begin{array}{l}0.184 \\
(3.00)\end{array}$ & *** \\
\hline Firm Size & $\begin{array}{l}-0.013 \\
(-3.08)\end{array}$ & *** & $\begin{array}{l}-0.007 \\
(-1.65)\end{array}$ & * & $\begin{array}{l}-0.007 \\
(-1.56)\end{array}$ & $\begin{array}{l}-0.013 \\
(-3.08)\end{array}$ & $* * *$ & $\begin{array}{l}-0.007 \\
(-1.67)\end{array}$ & * & $\begin{array}{l}-0.007 \\
(-1.56)\end{array}$ & \\
\hline$R O A$ & $\begin{array}{l}0.232 \\
(0.99)\end{array}$ & & $\begin{array}{c}0.248 \\
(1.04)\end{array}$ & & $\begin{array}{r}0.245 \\
(0.94)\end{array}$ & $\begin{array}{r}0.233 \\
(0.98)\end{array}$ & & $\begin{array}{r}0.250 \\
(1.05)\end{array}$ & & $\begin{array}{r}0.245 \\
(0.94)\end{array}$ & \\
\hline$R O A^{2}$ & $\begin{array}{l}1.818 \\
(1.48)\end{array}$ & & $\begin{array}{l}-0.925 \\
(-0.32)\end{array}$ & & $\begin{array}{l}7.656 \\
(2.56)\end{array}$ & $\begin{array}{l}1.824 \\
(1.48)\end{array}$ & & $\begin{array}{l}-0.808 \\
(-0.29)\end{array}$ & & $\begin{array}{l}7.658 \\
(2.57)\end{array}$ & ** \\
\hline BTM & $\begin{array}{l}-0.032 \\
(-3.41)\end{array}$ & *** & $\begin{array}{l}-0.003 \\
(-0.65)\end{array}$ & & $\begin{array}{l}0.005 \\
(1.15)\end{array}$ & $\begin{array}{l}-0.032 \\
(-3.39)\end{array}$ & $* * *$ & $\begin{array}{l}-0.003 \\
(-0.69)\end{array}$ & & $\begin{array}{l}0.005 \\
(1.15)\end{array}$ & \\
\hline Firm Age & $\begin{array}{l}-0.000 \\
(-0.01)\end{array}$ & & $\begin{array}{l}-0.013 \\
(-0.93)\end{array}$ & & $\begin{array}{l}-0.003 \\
(-0.28)\end{array}$ & $\begin{array}{l}-0.000 \\
(-0.01)\end{array}$ & & $\begin{array}{l}-0.012 \\
(-0.91)\end{array}$ & & $\begin{array}{l}-0.003 \\
(-0.28)\end{array}$ & \\
\hline Leverage & $\begin{array}{l}-0.073 \\
(-2.12)\end{array}$ & ** & $\begin{array}{l}-0.053 \\
(-1.54)\end{array}$ & & $\begin{array}{l}-0.050 \\
(-1.37)\end{array}$ & $\begin{array}{l}-0.073 \\
(-2.12)\end{array}$ & ** & $\begin{array}{l}-0.051 \\
(-1.49)\end{array}$ & & $\begin{array}{l}-0.050 \\
(-1.36)\end{array}$ & \\
\hline Intercept & $\begin{array}{l}0.115 \\
(1.55)\end{array}$ & & $\begin{array}{l}0.237 \\
(4.52)\end{array}$ & *** & $\begin{array}{l}0.067 \\
(1.18)\end{array}$ & $\begin{array}{l}0.115 \\
(1.59)\end{array}$ & & $\begin{array}{l}0.233 \\
(4.54)\end{array}$ & *** & $\begin{array}{l}0.067 \\
(1.18)\end{array}$ & \\
\hline $\begin{array}{l}\text { Industry Fixed Effects } \\
\text { Year/Quarter Fixed }\end{array}$ & Yes & & Yes & & Yes & Yes & & Yes & & Yes & \\
\hline Effects & Yes & & Yes & & Yes & Yes & & Yes & & Yes & \\
\hline $\mathrm{R}^{2}$ & $40.4 \%$ & & $39.3 \%$ & & $47.7 \%$ & $40.4 \%$ & & $39.5 \%$ & & $47.7 \%$ & \\
\hline $\mathrm{N}$ & 645 & & 569 & & 534 & 645 & & 569 & & 534 & \\
\hline $\mathrm{N}$ (Interim) & 121 & & 72 & & 33 & 121 & & 72 & & 33 & \\
\hline $\mathrm{N}$ (Aspiring) & 45 & & 27 & & 12 & 45 & & 27 & & 12 & \\
\hline N(Place-holding) & 76 & & 45 & & 21 & 76 & & 45 & & 21 & \\
\hline $\begin{array}{l}\text { Aspiring vs. Place-holdir } \\
\text { Prob }>\text { F }\end{array}$ & & & & & & $\begin{array}{l}-0.002 \\
(.9192)\end{array}$ & & $\begin{array}{r}0.036 \\
(.2856)\end{array}$ & & $\begin{array}{l}-0.001 \\
(.9809)\end{array}$ & \\
\hline
\end{tabular}

Table 6 shows the results of a multivariate regression using Ordinary Least Squares to examine the relation between abnormal discretionary expenses and interim CEOs. Columns 4-6 show the relation between abnormal discretionary expenses and the type of interim CEO. $q$ is the number of full quarters since the quarter of the turnover (e.g., $q=0$ represents the quarter of the turnover). Variables are defined in the appendix. The dependent variable (Discretionary expenses) is truncated at the $1^{\text {st }}$ and $99^{\text {th }}$ percentiles by $q$. All continuous independent variables are winsorized at the $1^{\text {st }}$ and $99^{\text {th }}$ percentiles by $q$. Year/quarter and industry (defined by two digit SIC codes) fixed effects are included in regressions. Standard errors have been clustered by firm. t-stats are reported in parentheses. ${ }^{*},{ }^{* *}$, and ${ }^{* * *}$ indicate statistical significance at the $10 \%, 5 \%$, and $1 \%$ level, respectively. 
Overall, I find no evidence consistent with interim CEOs acting myopically and managing earnings upwards. ${ }^{20}$ Rather, firms with aspiring interim CEOs have higher discretionary expenses subsequent to the quarter of the turnover, suggesting that aspiring interim CEOs are making decisions that may lower current earnings, but enhance long-run shareholder value. Additionally, there is some evidence that firms have lower performance-matched discretionary accruals during the first full quarter of the tenure of aspiring interim CEOs. Thus, the non-negative market reaction to the appointment of aspiring interim CEOs may be warranted.

\subsection{CEO Effort}

\subsubsection{Proxies for CEO effort}

I examine characteristics of management forecasts to shed preliminary light on CEO effort. ${ }^{21}$ Management forecasts are a voluntary disclosure, thus, by issuing forecasts, CEOs are choosing to invest time and energy (i.e., effort) to develop useful and accurate management forecasts. First, I examine whether place-holding interim CEOs are less likely issue management forecasts than permanent CEOs. Second, I examine whether forecasts issued by place-holding interim CEOs are less accurate than forecasts issued by permanent CEOs. Third, and lastly, I examine the number of measures (e.g., earnings per share and sales) forecasted. My sample decreases substantially when examining management forecasts. Thus, at this point, I only examine these characteristics through univariate analysis. All variables are defined in the appendix.

\footnotetext{
${ }^{20}$ In untabulated results, I examine the probability of firms with aspiring interim CEOs to meet or beat analyst forecasts. Generally, I found that there are no significant differences between aspiring interim CEOs and permanent CEOs. These results are also inconsistent with these interim CEOs acting myopically. I also control for the prior relationship between the firm and successor and find similar results, both qualitatively and quantitatively.

${ }^{21}$ Disentangling CEO effort from CEO ability and firm performance is challenging. I plan to explore CEO effort more in future iterations.
} 


\subsubsection{Results}

Table 7 presents univariate analysis of management forecast characteristics described in Section 5.2.1. I find that, prior to the turnover $(q=-1)$, there are fewer firms with aspiring interim successions that issue forecasts than firms with permanent successions that issue forecasts. However, subsequent to turnover $(q=1)$, these two groups do not exhibit differences in their likelihood to issue management forecasts. Furthermore and inconsistent with lack of effort, there are no significant differences with regards to likelihood of issuing management forecasts between place-holding interim CEOs and permanent CEOs.

Table 7: Management Forecasts

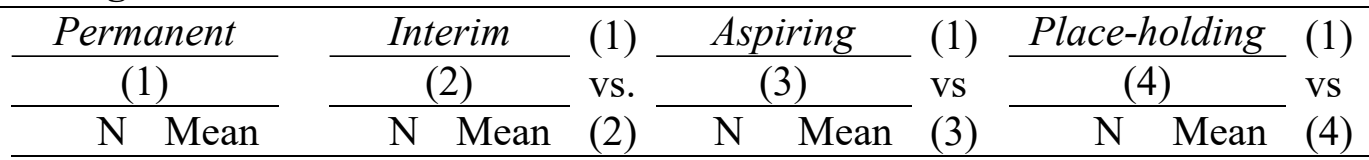

Panel A: Issue Forecast



Table 7 presents univariate analysis on management forecasts. Panel A shows the percentage of firms that issue a forecast during the quarter examined. Panel B shows the absolute forecast accuracy of management forecasts during the quarter examined. Panel $\mathrm{C}$ shows the number of measures forecasted by the firm during the quarter examined. $q$ is the number of full quarters since the quarter of the turnover (e.g., $q=0$ represents the quarter of the turnover). All variables are defined in the appendix. ${ }^{*},{ }^{* *}$, and ${ }^{* * *}$ indicate statistical significance at the $10 \%, 5 \%$, and $1 \%$ level, respectively.

Next, I examine forecast accuracy and show that place-holding interim CEOs are significantly less accurate during and subsequent to turnover than permanent CEOs. This finding is consistent with H2 (place-holding interim CEOs exerting less effort than permanent CEOs). 
Based on this small sample analysis, I find some preliminary evidence that interim CEOs exert less effort than permanent CEOs and that the negative market reaction to their appointment is warranted.

Lastly, Table 7 Panel C provides univariate analysis of the number of measures forecasted by interim CEOs. Prior to the appointment of an interim CEO, specifically a place-holding interim $\mathrm{CEO}$, firms forecast a significantly greater number of measures. However, following the turnover, these firms forecast a similar number of measures as firms with newly appointed permanent CEOs. This is inconsistent with place-holding interim CEOs exerting less effort than permanent CEOs. 


\section{CHAPTER 6}

\section{CONCLUSION}

Firms frequently appoint an interim CEO before a permanent CEO is appointed. However, there is little systematic evidence on the behavior of interim CEOs. I provide additional information regarding circumstances surrounding interim successions, types of interim CEOs, market perception of interim successions, and whether ex-post CEO behavior appears to be in line with market expectations.

Using a hand-collected sample of CEO turnovers, I show that interim successions are more likely to be the result of unanticipated departures (e.g., resignations and health-related) than permanent successions, which are more likely to be the result of anticipated departures (e.g., retirements). While interim CEOs in my sample stay in the interim position, on average, six months, approximately one-third of the interim CEOs are eventually appointed as permanent CEO.

I show that there are two groups of interim CEOs: those who aspire to a permanent CEO position (aspiring interim CEOs) and those who do not seek a permanent CEO position (placeholding interim CEOs). I conjecture that interim CEOs who were lower-level executives are more likely to be aspiring for a permanent CEO position, due to the increased monetary and nonmonetary benefits of the CEO position. On the other hand, I conjecture that interim CEOs who were non-executive directors are more likely to be holding the position only until the board appoints a permanent CEO. This conjecture is supported by the finding that these interim CEOs are significantly older and more likely to be close to retirement age.

While the market reacts similarly to appointments of aspiring interim CEOs and permanent CEOs, I find that there is a negative and significant market reaction to the appointment of place- 
holding interim CEOs, suggesting that the market may anticipate them to exert less effort than permanent CEOs. Additionally, the market reacts significantly more negatively to the appointment of place-holding interim CEOs than aspiring interim CEOs, suggesting that it anticipates more value-damaging behavior from place-holding interim CEOs than aspiring interim CEOs. In examining earnings management, I find no evidence that aspiring interim CEOs suffer from myopia relative to permanent CEOs. I find evidence consistent with place-holding interim CEOs exerting less effort while performing CEO duties. Specifically, they appear to create less accurate management forecasts. In general, these two types of interim CEOs appear to engage in different behavior than permanent CEOs. Thus, the nature of CEO successions is important and not all interim CEOs are created equal. Given these findings, future studies should separately examine behavior of different types of interim CEOs. 


\section{REFERENCES}

Antia, M., Pantzalis, C., \& Park, J. C. (2010). CEO decision horizon and firm performance: An empirical investigation. Journal of Corporate Finance, 16(3), 288-301.

Ballinger, G. A., \& Marcel, J. J. (2010). The use of an interim CEO during succession episodes and firm performance. Strategic Management Journal, 262-283.

Bamber, L. S., Jiang, J., \& Wang, I. Y. (2010). What's my style? The influence of top managers on voluntary corporate financial disclosure. The Accounting Review, 85(4), 1131-1162.

Bertrand, M., \& Schoar, A. (2003). Managing with style: The effect of managers on firm policies. The Quarterly Journal of Economics, 118(4), 1169-1208.

Bhojraj, S., Hribar, P., Picconi, M., \& McInnis, J. (2009). Making sense of cents: An examination of firms that marginally miss or beat analyst forecasts. The Journal of Finance, 64(5), 2361-2388.

Borokhovich, K. A., Parrino, R., \& Trapani, T. (1996). Outside directors and CEO selection. Journal of Financial and Quantitative Analysis, 31(3), 337-355.

Brochet, F., Faurel, L., \& McVay, S. (2011). Manager-specific effects on earnings guidance: An analysis of top executive turnovers. Journal of Accounting Research, 49(5), 1123-1162.

Campbell, T. C., Gallmeyer, M., Johnson, S. A., Rutherford, J., \& Stanley, B. W. (2011). CEO optimism and forced turnover. Journal of Financial Economics, 101(3), 695-712.

Carhart, M. M. (1997). On persistence in mutual fund performance. The Journal of Finance, 52(1), 57-82.

Cassell, C. A., Huang, S. X., \& Sanchez, J. M. (2013). Forecasting without consequence? Evidence on the properties of retiring CEOs' forecasts of future earnings. The Accounting Review, 88(6), 1909-1937.

Chen, G., Luo, S., Tang, Y., \& Tong, J. Y. (2015a). Passing probation: Earnings management by interim CEOs and its effect on their promotion prospects. Academy of Management Journal, 58(5), 1389-1418.

Chen, X., Cheng, Q., Lo, A. K., \& Wang, X. (2015b). CEO contractual protection and managerial short-termism. The Accounting Review, 90(5), 1871-1906.

Cheng, S. (2004). R\&D expenditures and CEO compensation. The Accounting Review, 79(2), 305328.

Clayton, M. C., Hartzell, J. C., \& Rosenberg, J. (2005). The impact of CEO turnover on equity volatility. The Journal of Business, 78(5), 1779-1808. 
Cohen, D. A., Dey, A., \& Lys, T. Z. (2008). Real and accrual-based earnings management in the pre-and post-Sarbanes-Oxley periods. The Accounting Review, 83(3), 757-787.

Cohen, D. A., \& Zarowin, P. (2010). Accrual-based and real earnings management activities around seasoned equity offerings. Journal of Accounting and Economics, 50(1), 2-19.

Coles, J. L., Daniel, N. D., \& Naveen, L. (2006). Managerial incentives and risk-taking. Journal of Financial Economics, 79(2), 431-468.

DeAngelo, L. E. (1988). Managerial competition, information costs, and corporate governance: The use of accounting performance measures in proxy contests. Journal of Accounting and Economics, 10(1), 3-36.

Dechow, P., Ge, W., \& Schrand, C. (2010). Understanding earnings quality: A review of the proxies, their determinants and their consequences. Journal of Accounting and Economics, 50(2), 344-401.

Dechow, P. M., \& Sloan, R. G. (1991). Executive incentives and the horizon problem: An empirical investigation. Journal of Accounting and Economics, 14(1), 51-89.

Dechow, P. M., Sloan, R. G., \& Sweeney, A. P. (1995). Detecting earnings management. The Accounting Review, 193-225.

Demerjian, P. R., Lev, B., Lewis, M. F., \& McVay, S. E. (2012). Managerial ability and earnings quality. The Accounting Review, 88(2), 463-498.

Denis, D. J., \& Denis, D. K. (1995). Performance changes following top management dismissals. The Journal of Finance, 50(4), 1029-1057.

DuCharme, L. L., Malatesta, P. H., \& Sefcik, S. E. (2001). Earnings management: IPO valuation and subsequent performance. Journal of Accounting, Auditing \& Finance, 16(4), 369-396.

Dyreng, S. D., Hanlon, M., \& Maydew, E. L. (2010). The effects of executives on corporate tax avoidance. The Accounting Review, 85(4), 1163-1189.

Fama, E. F., \& French, K. R. (1996). Multifactor explanations of asset pricing anomalies. The Journal of Finance, 51(1), 55-84.

Fields, T. D., Lys, T. Z., \& Vincent, L. (2001). Empirical research on accounting choice. Journal of Accounting and Economics, 31(1), 255-307.

Gibbons, R., \& Waldman, M. (1999). A theory of wage and promotion dynamics inside firms. The Quarterly Journal of Economics, 114(4), 1321-1358.

Graham, J. R., Harvey, C. R., \& Puri, M. (2013). Managerial attitudes and corporate actions. Journal of Financial Economics, 109(1), 103-121. 
Graham, J. R., Harvey, C. R., \& Rajgopal, S. (2005). The economic implications of corporate financial reporting. Journal of Accounting and Economics, 40(1), 3-73.

Guay, W. R. (1999). The sensitivity of CEO wealth to equity risk: an analysis of the magnitude and determinants. Journal of Financial Economics, 53(1), 43-71.

Gunny, K. A. (2010). The relation between earnings management using real activities manipulation and future performance: Evidence from meeting earnings benchmarks. Contemporary Accounting Research, 27(3), 855-888.

Hayes, R. M., \& Schaefer, S. (1999). How much are differences in managerial ability worth?. Journal of Accounting and Economics, 27(2), 125-148.

Healy, P. M., \& Wahlen, J. M. (1999). A review of the earnings management literature and its implications for standard setting. Accounting Horizons, 13(4), 365-383.

Hirshleifer, D., Low, A., \& Teoh, S. H. (2012). Are overconfident CEOs better innovators?. The Journal of Finance, 67(4), 1457-1498.

Hoitash, U., \& Mkrtchyan, A. (2017). Recruiting the CEO from the Board: Determinants and Consequences. Journal of Financial and Quantitative Analysis, forthcoming.

Hribar, P., \& Collins, D. W. (2002). Errors in estimating accruals: Implications for empirical research. Journal of Accounting Research, 40(1), 105-134.

Huson, M. R., Parrino, R., \& Starks, L. T. (2001). Internal monitoring mechanisms and CEO turnover: A long-term perspective. The Journal of Finance, 56(6), 2265-2297.

Intintoli, V. J., Zhang, A., \& Davidson, W. N. (2014). The impact of CEO turnover on firm performance around interim successions. Journal of Management \& Governance, 18(2), 541-587.

Jenter, D., \& Lewellen, K. A. (2017). Performance-induced CEO turnover. Working Paper.

Jones, J. J. (1991). Earnings management during import relief investigations. Journal of Accounting Research, 193-228.

Kalyta, P. (2009). Accounting discretion, horizon problem, and CEO retirement benefits. The Accounting Review, 84(5), 1553-1573.

Kaplan, S. N., \& Minton, B. A. (2012). How has CEO turnover changed?. International Review of Finance, 12(1), 57-87.

Korn Ferry (2014). Who wants to be CEO?

Kothari, S. P., Leone, A. J., \& Wasley, C. E. (2005). Performance matched discretionary accrual measures. Journal of Accounting and Economics, 39(1), 163-197. 
Malmendier, U., \& Tate, G. (2005). CEO overconfidence and corporate investment. The Journal of Finance, 60(6), 2661-2700.

Mooney, C. H., Semadeni, M., \& Kesner, I. F. (2014). The Selection of an Interim CEO Boundary Conditions and the Pursuit of Temporary Leadership. Journal of Management, 0149206314535433.

Murphy, K. J. (1986). Incentives, learning, and compensation: A theoretical and empirical investigation of managerial labor contracts. The Rand Journal of Economics, 59-76.

Murphy, K. J., \& Zimmerman, J. L. (1993). Financial performance surrounding CEO turnover. Journal of Accounting and Economics, 16(1-3), 273-315.

Naveen, L. (2006). Organizational complexity and succession planning. Journal of Financial and Quantitative Analysis, 41(3), 661-683.

Parrino, R. (1997). CEO turnover and outside succession a cross-sectional analysis. Journal of Financial Economics, 46(2), 165-197.

Perry, S. E., \& Williams, T. H. (1994). Earnings management preceding management buyout offers. Journal of Accounting and Economics, 18(2), 157-179.

Pourciau, S. (1993). Earnings management and nonroutine executive changes. Journal of Accounting and Economics, 16(1), 317-336.

PWC (2016). PWC 2016 Annual Corporate Directors Annual Survey.

Roychowdhury, S. (2006). Earnings management through real activities manipulation. Journal of Accounting and Economics, 42(3), 335-370.

Scharfstein, D. S., \& Stein, J. C. (1990). Herd behavior and investment. The American Economic Review, 465-479.

Schrand, C. M., \& Zechman, S. L. (2012). Executive overconfidence and the slippery slope to financial misreporting. Journal of Accounting and Economics, 53(1), 311-329.

Shleifer, A., \& Vishny, R. W. (1990). Equilibrium short horizons of investors and firms. The American Economic Review, 80(2), 148-153.

Spencer Stuart (2017). What Directors Think.

Smith, C. W., \& Stulz, R. M. (1985). The determinants of firms' hedging policies. Journal of Financial and Quantitative Analysis, 20(04), 391-405.

Smith Jr, C. W., \& Watts, R. L. (1982). Incentive and tax effects of executive compensation plans. Australian Journal of Management, 7(2), 139-157. 
Stein, J. C. (1988). Takeover threats and managerial myopia. Journal of Political Economy, 96(1), 61-80.

Stein, J. C. (1989). Efficient capital markets, inefficient firms: A model of myopic corporate behavior. The Quarterly Journal of Economics, 104(4), 655-669.

Strong, J. S., \& Meyer, J. R. (1987). Asset writedowns: Managerial incentives and security returns. The Journal of Finance, 42(3), 643-661.

Teoh, S. H., Welch, I., \& Wong, T. J. (1998). Earnings management and the long-run market performance of initial public offerings. The Journal of Finance, 53(6), 1935-1974.

Weisbach, M. S. (1995). CEO turnover and the firm's investment decisions. Journal of Financial Economics, 37(2), 159-188. 


\section{APPENDIX}

\section{VARIABLE DEFINITIONS}

\begin{tabular}{|c|c|}
\hline Varia & Description \\
\hline Aspiring & $\begin{array}{l}\text { Indicator variable set equal to one if the CEO is interim and was employed } \\
\text { by the firm in a non-CEO position immediately prior to CEO appointment } \\
\text { and zero otherwise (Source: } 8 \text {-K or attached press release) }\end{array}$ \\
\hline $\operatorname{avgATQ}$ & Average assets during the quarter (Source: Compustat) \\
\hline$B T M$ & Book to market ratio $\left((a t q-l t q) /\left(p r c c q^{*} c s h o q\right)\right)$ (Source: Compustat) \\
\hline$C A R(0,1)$ & $\begin{array}{l}\text { Cumulative abnormal returns for the firm adjusted for Fama and French } \\
\text { (1996) and Carhart (1997) factors over the two-day window where day } \\
\text { zero is the day the CEO succession is announced }\end{array}$ \\
\hline $\begin{array}{l}\text { Discretionary } \\
\text { Accruals }\end{array}$ & $\begin{array}{l}\text { Signed discretionary accruals, see Section 5.1.1.1. for additional detail } \\
\text { (Source: Compustat) }\end{array}$ \\
\hline $\begin{array}{l}\text { Discretionary } \\
\text { Expenses }\end{array}$ & $\begin{array}{l}\text { Abnormal discretionary expenses, see Section 5.1.1.2. for additional detail } \\
\text { (Source: Compustat) }\end{array}$ \\
\hline DISX & $\begin{array}{l}\text { Discretionary expenses scaled by average assets }(X R D Q+ \\
X S G A Q) / \text { avgATQ (Source: Compustat) }\end{array}$ \\
\hline Firm Age & $\begin{array}{l}\text { Natural log of the age of the firm, in years (current year - yearl) (Source: } \\
\text { Compustat) }\end{array}$ \\
\hline Firm Size & $\begin{array}{l}\text { Natural log of the market capitalization }\left(\operatorname{prcc}^{*}{ }^{*} \operatorname{cshoq}\right) \text { (Source: } \\
\text { Compustat) }\end{array}$ \\
\hline Forced Tur & $\begin{array}{l}\text { Indicator variable set equal to one if the reason stated for the turnover is } \\
\text { forced or if the predecessor is less than sixty years old and the reason stated } \\
\text { is not related to health, a position at another firm, or a retirement } \\
\text { announced at least six months prior to the turnover, following Parrino } \\
\text { (1997) and zero otherwise (Source: Compustat and 8-K/related press } \\
\text { release) }\end{array}$ \\
\hline Forecast Accuracy & $\begin{array}{l}\text { Absolute accuracy of the management forecast scaled by price (Source: } \\
\text { I/B/E/S) }\end{array}$ \\
\hline Health Related & $\begin{array}{l}\text { Indicator variable equal to one if the firm stated health reasons for the } \\
\text { departure of the predecessor and zero otherwise (Source: } 8-\mathrm{K} \text { or attached } \\
\text { press release) }\end{array}$ \\
\hline Interim & $\begin{array}{l}\text { Indicator variable set equal to one if the successor is an interim CEO (e.g. } \\
\text { "interim," "acting," "temporary," or CEO "until search is completed") and } \\
\text { zero if there is no indication that the successor is an interim CEO (Source: } \\
8-\mathrm{K} \text { or attached press release) }\end{array}$ \\
\hline Issue Forecast & $\begin{array}{l}\text { he if the firm had a management } \\
\text { herwise (Source: } \mathrm{I} / \mathrm{B} / \mathrm{E} / \mathrm{S} \text { ) }\end{array}$ \\
\hline
\end{tabular}


lagSALEQ

Leverage

LLE - CFO

LLE - Other

LLE -

President/COO

$L L E-V P$

Lower-Level

Executive

Merge

Missing

Explanation

NED - Chairman

NED - Non-

Chairman

Non-Executive

Director

Not Stay

Number of

Measures

Other
Sales/Turnover (Net) for the previous quarter (Source: Compustat)

Total debt $(d l c q+d l t t q)$ divided by total assets (atq) (Source: Compustat) Indicator variable that is equal to one if the successor CEO was a Chief Financial Officer of the firm immediately prior to appointment as CEO and zero otherwise (Source: 8-K or attached press release)

Indicator variable that is equal to one if the successor CEO was a lowerlevel executive of the firm immediately prior to appointment as CEO, but not in a President, COO, CFO, or VP position and zero otherwise (Source: 8 -K or attached press release)

Indicator variable that is equal to one if the successor CEO was a President or Chief Operating Officer of the firm immediately prior to appointment as $\mathrm{CEO}$ and zero otherwise (Source: $8-\mathrm{K}$ or attached press release)

Indicator variable that is equal to one if the successor CEO was a Vice President of the firm immediately prior to appointment as CEO and zero otherwise (Source: 8-K or attached press release)

Indicator variable that is equal to one if the successor CEO was a lowerlevel executive of the firm immediately prior to appointment as CEO and zero otherwise (Source: 8-K or attached press release)

Indicator variable that is equal to one if the interim CEO was present until the firm merged with another firm (Source: $8-\mathrm{K}$ or attached press release)

Indicator variable equal to one if the firm does not state a reason for the departure of the predecessor and zero if any reason is stated for the departure (Source: 8 -K or attached press release)

Indicator variable that is equal to one if the successor CEO was a nonexecutive chairman of the board immediately prior to appointment as CEO and zero otherwise (Source: 8-K or attached press release)

Indicator variable that is equal to one if the successor CEO was a nonexecutive director, but not chairman, immediately prior to appointment as CEO (Source: 8-K or attached press release)

Indicator variable that is equal to one if the successor CEO was a nonexecutive director of the firm immediately prior to appointment as CEOand zero otherwise (Source: $8-\mathrm{K}$ or attached press release)

Indicator variable that is equal to one if the interim CEO does not stay with the firm immediately subsequent to the appointment of a permanent CEO and zero otherwise (Source: 8-K or attached press release)

Number of different measures for which the firm issued a forecast during the quarter (Source: $\mathrm{I} / \mathrm{B} / \mathrm{E} / \mathrm{S}$ )

Indicator variable that is equal to one if the successor CEO was not previously a non-executive director or lower-level executive of the firm, and zero otherwise (Source: 8-K or attached press release) 
Other - External

Other-Other

Other Explanation

PerformanceMatched DACC

Place-holding

PPEGTQ

Predecessor Age

Predecessor Stay

Predecessor

Tenure

$q$

Q4

Raided Turnover

Resign

Retire
Indicator variable that is equal to one if the successor CEO had no relationship with the firm immediately prior to appointment as CEO, and zero otherwise (Source: 8-K or attached press release)

Indicator variable that is equal to one if the successor CEO had a relationship with the firm immediately prior to appointment as CEO, but was not a non-executive director or lower-level executive of the firm and zero otherwise (Source: 8-K or attached press release)

Indicator variable equal to one if the firm states a reason for the departure and it is not related to health reasons, retirement, or resignation and zero otherwise (Source: 8-K or attached press release)

Performance-matched discretionary accruals, see Section 5.1.1.1. for additional detail (Source: Compustat)

Indicator variable set equal to one if the CEO is interim and was a nonexecutive director of the firm immediately prior to CEO appointment and zero otherwise (Source: 8-K or attached press release)

Property, Plant and Equipment - Total (Gross) - Quarterly (Source: Compustat)

Age (in years) of the predecessor in the quarter prior to the turnover (Source: Execucomp)

Indicator variable set equal to one if the firm states that the predecessor will stay with the firm in any capacity following the succession and zero if there is no indication that the predecessor will stay with the firm in any capacity following the succession (Source: $8-\mathrm{K}$ or attached press release)

Number of years the predecessor was present at the firm (Source: Execucomp and 8-K or attached press release)

Number of full quarters since the quarter of the turnover, where $\mathrm{q}=0$ is the quarter of the turnover (Source: ExecuComp or $8-\mathrm{K}$ and attached press release)

Indicator variable that is equal to one if the quarter of observation was the fourth quarter of the fiscal year (Source: Compustat)

Indicator variable that is equal to one if the succession occurred due to the predecessor CEO accepting a position at another firm and zero otherwise (Souce: 8-K or attached press release)

Indicator variable equal to one if the firm stated that the predecessor is resigning, terminating, stepping down, or relinquishing the CEO position and the turnover is not related to health reasons or retirement and zero otherwise (Source: 8-K or attached press release)

Indicator variable equal to one if the firm stated that the predecessor is retiring and not related to health reasons and zero otherwise (Source: 8-K or attached press release) 
SALEQ

Stay

Stay - CEO

Stay - Chairman

Stay - Other

Stay - Transition

Successor Age

TACC
Sales/Turnover (Net) (Source: Compustat)

Indicator variable that is equal to one if the interim CEO stays with the firm in some position immediately subsequent to the appointment of a permanent CEO and zero otherwise (Source: 8-K or attached press release) Indicator variable that is equal to one if the interim CEO is appointed permanent CEO and zero if the interim stays with the firm in a non-CEO position (Source: $8-\mathrm{K}$ or attached press release)

Indicator variable that is equal to one if the predecessor CEO stayed with the fir $\mathrm{m}$ in the Chairman position and zero otherwise (Source: $8-\mathrm{K}$ or attached press release)

Indicator variable that is equal to one if the interim $\mathrm{CEO}$ is not appointed permanent CEO, but remains with the firm in some position and zero if the interim CEO is appointed permanent CEO (Source: $8-\mathrm{K}$ or attached press release)

Indicator variable that is equal to one if the predecessor CEO stayed with the firm in a transitional position and zero otherwise (Source: $8-\mathrm{K}$ or attached press release)

Age (in years) of the successor CEO in the quarter of the turnover (Source: Execucomp, 8-K, or attached press release)

Total accruals scaled by average assets (IBCY - (OANCFY $X I D O C Y$ ))/avgATQ (Source: Compustat) 